NBER WORKING PAPER SERIES

\title{
DO WTO MEMBERS HAVE A MORE LIBERAL TRADE POLICY?
}

\author{
Andrew K. Rose \\ Working Paper 9347 \\ http://www.nber.org/papers/w9347 \\ NATIONAL BUREAU OF ECONOMIC RESEARCH \\ 1050 Massachusetts Avenue \\ Cambridge, MA 02138 \\ November 2002
}

For comments, I thank: Barry Eichengreen, Ricardo Hausmann, Doug Irwin, and Janet Yellen, and seminar participants at Claremont and Princeton. For data access, I thank: Sebastian Edwards, David Greenaway, Ann Harrison, Lant Pritchett, and Scott Kastner. I thank Princeton University's International Economics Section for hospitality during the course of working on this paper. The Stata 7 data set, key output, and a current version of the paper are available at my website. The views expressed herein are those of the authors and not necessarily those of the National Bureau of Economic Research.

(C) 2002 by Andrew K. Rose. All rights reserved. Short sections of text, not to exceed two paragraphs, may be quoted without explicit permission provided that full credit, including (C) notice, is given to the source. 
Do WTO Members have More Liberal Trade Policy?

Andrew K. Rose

NBER Working Paper No. 9347

November 2002

JEL No. F13, F15

\title{
ABSTRACT
}

This paper uses 68 measures of trade policy and trade liberalization to ask if membership in theWorld Trade Organization (WTO) and its predecessor the General Agreement on Tariffs and Trade (GATT) is associated with more liberal trade policy. Almost no measures of trade policy are significantly correlated with GATT/WTO membership. Trade liberalizations, when they occur, usually lag GATT entry by many years, and the GATT/WTO often admits countries that are closed and remain closed for years. The exception to the negative rule is that WTO members tend to have slightly more freedom as judged by the Heritage Foundation's index of economic freedom.

\author{
Andrew K. Rose \\ Haas School of Business \\ University of California \\ Berkeley, CA 94720-1900 \\ and NBER \\ arose@haas.berkeley.edu
}




\section{Introduction and Motivation}

Social scientists - especially economists - love to analyze international organizations and their policies. The International Monetary Fund scrutinizes the effects of its own programs, as do its critics. There is enormous controversy over the effectiveness and side effects of World Bank programs, conducted both within the Bank and outside. It is thus curious that one of the currently most controversial international organizations - the World Trade Organization (WTO) - has largely escaped this scrutiny. There is, to my knowledge, no rigorous empirical literature that examines whether the WTO, and its predecessor the General Agreement on Tariffs and Trade (GATT), have actually succeeded in terms of their own mandate, namely trade policy. In this short paper, I begin to fill that void by providing a brief statistical analysis of the effects of GATT/WTO membership on trade policy. ${ }^{1}$

The WTO is not only of interest because of a gap in the literature. Much of the radical left thinks that the WTO is the source of much evil since, by liberalizing trade, the WTO degrades the environment, perpetuates poverty, increases inequality, and much else. The right uses the same premise to conclude that, in freeing trade, the WTO does just the opposite. In this paper I ask: is the antecedent itself correct? Is there compelling evidence that the GATT/WTO has actually liberalized trade policy ${ }^{2}$

To be more precise, the question I ask in this paper is whether trade policy is systematically more liberal for members of the GATT/WTO than for non-members. This immediately raises an important issue, namely "How does one measure trade policy?" In fact, it is widely acknowledged that there is no perfect measure of trade policy. This is true when one seeks to compare countries at a point in time, and even more so when one wishes to compare the trade policy of a given country at different points of time. As a result I look at over sixty 
measures of trade policy. In fact, I examine all quantitative measures of trade policy that I have been able to find. ${ }^{3}$

It turns out that membership in the GATT/WTO is not significantly correlated with the vast majority of trade policy measures. Thus I conclude that there is little evidence that membership in the GATT/WTO has actually liberalized trade policy. The exception is the Heritage Foundation's “Index of Economic Freedom” which usually indicates that GATT/WTO members enjoy somewhat more economic freedom than non-members.

\section{The Mandate of the WTO}

Does anyone believe that the GATT/WTO has been liberalizing international trade? I now confirm conventional wisdom and common sense with some brief evidence.

The WTO certainly thinks it is following its mandate of liberalizing and maintaining

liberal trade. For instance, the many self-provided descriptions of the WTO include:

"By lowering trade barriers, the WTO's system also breaks down other barriers between peoples and nations..."

"The WTO is the only international body dealing with the rules of trade between nations. At its heart are the WTO agreements, the legal ground-rules for international commerce and for trade policy. The agreements have three main objectives: to help trade flow as freely as possible, to achieve further liberalization gradually through negotiation, and to set up an impartial means of settling disputes"

"The WTO agreements cover goods, services and intellectual property. They spell out the principles of liberalization, and the permitted exceptions. They include individual countries' commitments to lower customs tariffs and other trade barriers, and to open and keep open services markets."4

Similarly and consistently, the third paragraph of the GATT provides motivation for the founding members: 
"Being desirous of contributing to these objectives [raising standards of living, ensuring full employment, ...] by entering into reciprocal and mutually advantageous arrangements directed to the substantial reduction of tariffs and other barriers to trade and to the elimination of discriminatory treatment in international commerce ..."

It also seems safe to say that most economists think that the GATT has been at least moderately successful in liberalizing trade. For instance, Bagwell and Staiger (1999, p. 215) begin their paper "The central role played by the General Agreement on Tariffs and Trade (GATT) in shaping postwar trade policy is widely accepted." Krueger (1998, pp 2-3) writes: “...the growth and liberalization of the international trading system has been the most prominent success of the postwar period ... the great liberalization of tariffs and trade in the post-war period was achieved under the auspices of the GATT ..." Irwin (1995, pp 326-327) writes:

“... the major goal of the GATT founders was achieved: once again [as before WWI], the world economy experienced expanding international commerce facilitated by lowering trade barriers, a record that continued after the breakdown of the fixed-exchange-rate regime in the early 1970s... the GATT process with U.S. leadership did secure the very real accomplishments of eliminating a host of impediments to international trade."

"The GATT scraped along at times, but had a distinct, downward ratchet effect on world trade barriers. For this reason, in spite of its small size and uncertain place as an economic institution, the GATT's long-run impact on the world economy has (arguably) been more significant than either that of the World Bank or the International Monetary Fund."

The next section of the paper discusses the measurement of trade policy, while section 3 presents the methodology. The results are presented in the next section, and some interpretation, caveats and conclusions are in the final section. 


\section{Measures of Trade Policy from the Literature}

All agree that measuring trade policy is a messy business. Still, there are a large number of economists who have made the heroic undertaking, usually to determine the effect of trade policy on growth. Dollar (1992), Sachs and Warner (1995), Harrison (1996), Edwards (1997), and Greenaway et. al. (2002) are recent example of this literature. This field has been famously criticized by Rodriguez and Rodrik (2000), who present a wide-ranging critique of the literature. They focus much of their attention on the issue of measuring trade policy, and are especially critical of Dollar's (1992) price-based measures of trade distortion and the measures developed by Sachs and Warner. Clearly relying on one or even a few measures of trade policy would be risky. This is especially true since Pritchett (1996) has demonstrated that a number of different measures of trade policy are mutually uncorrelated.

I do not attempt to provide a new measure of trade policy here. On the contrary, I want to exploit as many measures as possible that have been created and used by others. My empirical strategy is to examine a mass of trade policy measures, and search for indications of a connection between these indicators of trade policy and GATT/WTO membership.

The strength of this approach relies on the facts that: a) I employ a large number of trade policy indicators that are broad-ranging and comprehensive in scope, which; b) were not created by me; and c) were gathered or created by others for a different purpose (usually to link trade policy to growth). These three features of the data set should reduce any bias in my study. One potential cost of this strategy is the need to guard against the natural tendency to over-interpret the results, since the measures are far from independent.

I restrict my attention to the 168 countries that are covered in the Penn World Table mark 6, from 1950 through 1998, since I often condition on population and real GDP per capita data 
taken from that source. ${ }^{5}$ This is not a serious limitation; the countries are listed in an appendix, along with the date of GATT/WTO accession.

\section{A Taxonomy of Trade Policy Measures}

Since there are so many indicators of trade policy, I organize them into seven groups:

1. Openness (e.g., the ratio of trade or imports to GDP), an outcome-based measure,

2. Trade flows adjusted for country-characteristics (outcome-based),

3. Tariffs (policy incidence-based),

4. Non-tariff barriers (incidence-based),

5. Informal or qualitative measures,

6. Composite indices, and

7. Measures based on price outcomes.

Table 1 provides a comprehensive tabulation of the individual measures of trade policy, sorted into these seven classes. The table includes the sample period for which the data are available, the data source, number of observations, and proportion of observations from GATT/WTO members. I now discuss these measures in somewhat greater detail; readers are referred to the original articles for more discussion.

(Parenthetically, I note that one possible measure is striking by its omission. No study, to the best of my knowledge, uses membership in the GATT/WTO as an indicator of trade liberalization.)

\section{Openness}

The most obvious measure of openness is simply aggregate exports and imports divided by GDP. This measure is available from the Penn World Table mark 6 for a broad range of countries from 1950 through 1998. 
Pritchett (1996) uses another 16 cross-sectional measures of trade penetration for developing countries. These are provided for two different years (1982 and 1985) for four different aggregates (overall, and the manufacturing, agricultural and resources sectors). Each of these eight measures is available both for imports alone, and for total trade derived from the World Bank's TARS system. ${ }^{6}$

\section{Tariffs}

A number of measures of tariffs are available. All are affected by the well-known fact that tariff revenues divided by total imports is a downward-biased measure of tariff rates, since highly taxed imports tend not to be imported. Nevertheless, these measures may work well in practice. Rodriguez and Rodrik (2000, p. 316) write:

"We are especially struck and puzzled by the proliferation of indexes of trade restrictions. It is common to assert in this literature that simple tradeweighted tariff averages or non-tariff coverage ratios - which we believe to be the most direct indicators of trade restrictions - are misleading as indicators of the stance of trade policy. Yet we know of no papers that document the existence of serious biases in these direct indicators, much less establish that an alternative indicator performs better (in the relevant sense of calibrating the restrictiveness of trade regimes). An examination of simple averages of taxes on imports and exports and NTB coverage ratios leaves us with the impression that these measures in fact do a decent job of rank-ordering countries according to the restrictiveness of their trade regimes."

The tariff measure referred to by Rodriguez and Rodrik is available from the World Development Indicators from 1970 though the end of the sample in 1998 (with gaps).

Alternative measures are available in cross-sections from: 1) the Barro-Lee data set (Lee's measure of own-import weighted tariff rates on intermediate inputs and capital goods, constructed from UNCTAD data); 2) Edwards (1996) who collected data on total revenue from 
taxes on international trade as a proportion of total trade; 3) Pritchett (1996) who provides weighted average total import charges for four different aggregates for a number of countries; and 4) Heitger (1987) who tabulates point estimates and (within-country, inter-sectoral) standard deviations for effective rates of protection for a number of countries.

\section{Non-Tariff Barriers}

The coverage of non-tariff barriers (NTBs) in terms of total imports is another widely used measure of trade policy. It is widely recognized that the presence of NTBs is a potentially poor substitute for the importance or intensity of the NTBs, so this measure of trade policy is certainly measured with error. I take advantage of the NTB coverage cross-section available from the Barro-Lee data set, which provides information on own-import weighted non-tariff frequency on intermediate inputs and capital goods, again derived from UNCTAD sources. I also use the measures from Pritchett (1996) who provides analogues for four different aggregates for a number of countries in 1987.

\section{Informal or Qualitative Measures}

A number of more informal or qualitative measures of trade policy have been created, and I try to take full advantage of them all. For instance, the World Bank has created measures of "trade orientation" for two different periods of time for forty countries. These range from one (“strongly outward oriented") through four ("strongly inward oriented"). The Heritage Foundation has created an index of overall "economic freedom." This measure runs from one (a score signifying institutions and policies most conducive to economic freedom) through five (least conducive). The overall index of economic freedom is determined by ten factors, of which 
one is "trade policy," also organized on a scale from one (very low protectionism) through five (very high protectionism). The trade policy factor is primarily determined by tariff rates, adjusted for NTB coverage and corruption.

The NBER study lead by Anne Krueger has created measures of the phase of trade liberalization. These range from one through five (most free). Finally, Edwards (1997) uses cross-country rankings of trade orientation derived from regression-based indices of import distortions (originally developed by Wolf) for two different years.

\section{Composite Measures}

Harrison (1996, p. 427) describes a number of trade policy measures for developing countries, each of which is available as a panel variable and is used by her to study the effects of trade policy on growth. Three of these are composites. They include: 1) an index "derived using country-specific information on exchange rate and commercial policies" taken from Papageorgiuo et al (where higher values indicate more liberal policy; this is denoted "Index from FX and commercial policy" below); 2) an index "calculated using country sources on tariffs and non-tariff barriers" derived by the World Bank (again, higher values indicate more liberal policy; this composite is denoted "Index from Tariffs and NTBs" below); and 3) a measure of indirect bias against agriculture resulting from industrial protection and exchange rate overvaluation (where higher means lower protection). Edwards (1997) also provides measures of openness, as computed by Sachs and Warner, for different decades. 


\section{Measures based on Residuals from Trade Equations}

Leamer has used deviations of actual trade from trade as predicted by an empirical factorproportions model of trade to measure trade policy. I use this measure (as supplied by Edwards, 1997). Pritchett (1996) has provided a number of variations on this theme using data for 1982 and a number of different sub-aggregates. A less structural approach is taken by Hiscox and Kastner (2002). They use fixed country-year residual effects from two gravity models of trade (a simple version which links imports to GDP and distance, and an augmented one which adds measures of wealth, land, and capital) to derive measures of trade policy orientation.

\section{Price-Based Measures}

Above and beyond her three indices of trade policy, Harrison (1996) provides a number of price-based measures of trade policy that are available as panel variables. These include: 1) the black market foreign exchange premium; 2) a country's "movement to international prices" derived using Penn World Table data as the benchmark; and 3) a modified version of Dollar's (1992) well-known "price distortion" index (where high values indicate distortion). ${ }^{7}$ Pritchett (1996) also provides measures of both the level and variability of Dollar's price distortion measure.

\section{Methodology}

I start with simple regression techniques, in order to see whether straightforward methods reveal gross obvious differences in observable trade policy between GATT/WTO members and non-members. My cross-sectional evidence is derived from equations of the form: 


$$
\mathrm{TP}_{\mathrm{i}}=\alpha+\beta \mathrm{GATTWTO}_{\mathrm{i}}+\Sigma_{\mathrm{j}} \gamma_{\mathrm{j}} \mathrm{X}_{\mathrm{j}}+\varepsilon_{\mathrm{i}}
$$

while my panel evidence is derived from equations of the form:

$$
\mathrm{TP}_{\mathrm{it}}=\alpha+\beta \mathrm{GATTWTO}_{\mathrm{it}}+\Sigma_{\mathrm{j}} \gamma_{\mathrm{j}} \mathrm{X}_{\mathrm{jt}}\left\{+\delta_{\mathrm{i}}\right\}\left\{+\phi_{\mathrm{t}}\right\}+\varepsilon_{\mathrm{it}}
$$

where i denotes a country, $\mathrm{t}$ denotes time, and:

- TP denotes a measure of trade policy,

- GATTWTO is a binary dummy variable which is unity for GATT/WTO members,

- $\mathrm{X}$ is a set of conditioning variables,

- $\alpha$ and $\left\{\gamma_{j}\right\}$ are nuisance coefficients,

- $\left\{\delta_{\mathrm{i}}\right\}$ and $\left\{\phi_{\mathrm{t}}\right\}$ are a comprehensive set of nuisance country- and time-specific fixed effects, and

- $\varepsilon$ is a well-behaved residual.

The coefficient of interest to me is $\beta$. If $\beta$ is insignificantly different from zero, there is no evidence that countries inside the GATT/WTO have trade policies different from those outside the multilateral trade system. In this case there is no evidence that GATT/WTO membership is associated with more liberal trade policy.

I estimate $\beta$ for my cross-sectional measures in three different ways: 1) with ordinary least squares (OLS) without augmenting variables, i.e., setting $\gamma_{\mathrm{j}}=0 \forall \mathrm{j}$; 2) with OLS but adding three augmenting variables ("remoteness" and the natural logarithms of population and real GDP per capita); and 3) with instrumental variables. Data for population and real GDP per capita come from the Penn World Table 6. Remoteness represents distance from a country to output in 
the rest of the world. It is defined for country $i$ as the inverse of the mean of log real GDP for country j divided by the log of distance between $\mathrm{i}$ and $\mathrm{j}$; Fiji and New Zealand are the most remote countries in the sample. ${ }^{8}$

I pursue the same strategy for my panel variables, but also use fixed effects in four combinations: a) none; b) only year-specific; c) only country-specific; and d) both year and country-specific fixed effects.

I include remoteness, population, and real GDP per capita to account for some wellknown features of trade policy. Large and poor countries are systematically more protectionist, as noted by Rodrik (1995) who argues that richer countries have more developed tax structures; smaller countries may also proportionately have more to gain from trade.

My instrumental variable estimates represent a crude first effort to handle both simultaneity bias and measurement error. I use the country's "polity" score as an instrumental variable for GATT/WTO membership. I take this variable from the Polity IV data set, which is available for a wide range of countries through the end of my sample. This variable ranges from -10 for strongly autocratic systems to +10 for strongly democratic systems. ${ }^{9}$

\section{Regression Results}

I tabulate estimates of $\beta$ for my cross-sectional measures of trade policy in Table 2 along with the absolute value of the t-statistic that tests the hypothesis of no effect of GATT/WTO membership on trade policy (computed with a robust standard error). Table 3 contains analogues for the panel measures of trade policy. Coefficients that are significantly different from zero at the 5\% (1\%) level are marked with one (two) asterisk(s). 
The impression one gets upon scanning Table 2 is one of ... nothingness. There are 51 cross-sectional measures of trade policy (16 of openness; 8 of tariffs; 5 of NTBs; 5 informal; 2 composites; 13 based on residuals; and 2 based on prices), with three coefficients recorded for each measure (OLS bivariate; OLS with augmenting variables; and IV bivariate). Of the 153 coefficients, 6 are significantly different from zero at the 5\% significance level; 2 of these are significantly different at the $1 \%$ level. The only coefficient which is significantly different from zero in more than one perturbation is the Heritage Foundation's index (it is significantly different from zero twice); more on this below. Further, the effect of GATT/WTO membership is often perversely signed. For instance, members are often less open than non-members, with higher tariffs and NTB coverage.

The results in Table 3, which exploit panel data, are somewhat stronger. 156 coefficients are recorded (= 13 measures of trade policy x 4 possible sets of fixed effects combinations $\mathrm{x} 3$ estimation variations [OLS bivariate/OLS augmented/IV bivariate]). Of these, 17 are significantly different from zero at the $1 \%$ significance level, and an additional 8 are significant at the 5\% level. The results are not generally robust, with one exception. The index of economic freedom (IEF) often indicates significantly more freedom for WTO members. More precisely, six of the twelve coefficients are significantly different from zero at the $1 \%$ level (though none with country fixed effects). Another is significant at the $5 \%$ level, and all indicate more freedom for GATT/WTO members. The point estimates indicate that GATT/WTO members enjoy about a half-point more economic freedom on a five-point scale. (By way of illustration in 1998, Ireland and Australia both scored 1.9 on the IEF while France and Italy each scored 2.4.)

Two of the estimates for the trade policy measure of the IEF are significant at the $1 \%$ level, and another two at the 5\% level (again, none with country fixed effects). The relationships 
between other trade policy measures and membership seem even more sensitive to the estimation technique. For instance, tariff rates are sometimes positively linked to membership, sometimes negatively linked and are never significantly linked when country effects are included. Finally, the OLS effects are almost always economically small (as well as statistically insignificant), while the IV point estimates vary wildly in magnitude.

It seems there is little obvious connection between GATT/WTO membership and trade policy. Figure 1 contains corroborating graphical evidence in the form of histograms for two standard measures of trade policy (the Barro-Lee measures of tariffs and NTB coverage), each split by GATT membership. No dramatic differences between GATT members and outsiders pop out in either NTB coverage or tariff rates. Outsiders typically have slightly less NTB coverage and slightly higher tariffs; neither of these effects is significant at conventional levels. ${ }^{10}$

Insignificant differences can stem either from similar means or large variances (or both). Which is responsible for these results? We can shed light on this by examining Figure 2, an analogue to the first figure that focuses on import duties as a percentage of imports. Histograms are provided for eight individual years between 1977 (when the sample of countries with data became large) and 1998, both for GATT/WTO members and non-members. While there are never significant differences in mean tariffs between members and non-members, the reason varies over time. In the early years non-members had higher average tariffs (23\%) than GATT members (10\%), but the variation in tariffs across non-members was sufficiently high that the differences are insignificant. ${ }^{11}$ After the early to mid 1980s, the differences in both average tariffs and their cross-country variation become small, so the insignificant t-tests result from similar means. 
Further confirmation of the loose relationship between GATT/WTO membership and trade policy is available in Figure 3. This presents a graphical "event study" for the effects of accession on nine measures of trade policy (those that can be quantified over time). For instance, the top-left graphic shows the mean level of openness (the ratio of exports plus imports to GDP) at the time of entry for countries acceding between 1950 through 1998, along with a plus/minus two standard deviation confidence interval. To the right of the vertical line (which marks accession) are data for the years after entry; the years preceding accession are graphed to the left. The horizontal line marks the average level of openness for those inside the GATT/WTO.

The event study graphics allow one to see what happens to trade policy measures for a typical country acceding to the GATT/WTO. And not much happens. For instance, a typical accession country has an openness ratio of $73.1 \%$ five years before joining (somewhat higher than the GATT/WTO average of 64.7\%). But five years after accession, the joiners only have openness ratios of $70.4 \%$. Similarly, tariffs rise (again, insignificantly) from $12.5 \%$ to $13.1 \%$ of imports. Indeed, none of the nine measures of trade policy change significantly; most measures are insignificantly different from those inside the system for the five years before, during and after accession.

Perhaps a simple example can make the case clearly. Mexico joined the GATT in 1986, at which time its tariffs averaged $6.4 \%$ of imports. Yet even five years after accession, the Mexican tariff rate was 7.1\%; Mexican tariffs did not really fall until NAFTA began in the mid1990s. Nor is Mexico special; for instance, average tariffs were higher even five years after Colombia and Venezuela acceded in 1981 and 1990 respectively.

It seems that none of the 64 measures of trade policy is strongly and consistently tied to GATT/WTO membership, with the exception of the index of economic freedom. The majority 
of the coefficients linking trade policy to membership are small; not many more coefficients are significantly different from zero than would be expected if the true effect of membership on policy is nil. ${ }^{12}$ To summarize, any effect that the WTO has (and the GATT had) on trade policy is either subtle or weak. ${ }^{13}$

\section{Liberalization Results}

The previous section examined the linkage between the levels of trade policy and membership in the GATT/WTO. More evidence is available by looking at dramatic regime changes in trade policy - liberalizations - and membership. I now pursue this tack briefly.

Table 4a presents the developing countries described as "closed" by Sachs and Warner (1995). It is interesting to note that 28 of the 35 closed developing countries were in the GATT at the time the list was composed in late 1994; most of these had been members for over twenty years. That is, the GATT repeatedly admitted countries that were closed (at least by the SachsWarner criteria) and remained closed following entry.

Table 4b lists 22 countries classified as "developed" by Sachs and Warner; I also tabulate the Sachs-Warner year of opening and the year the country acceded to the GATT. Two of the countries remained closed, though both are members of the GATT/WTO. Of the remaining twenty, Spain and Switzerland liberalized before acceding to the GATT. Nearly all the others liberalized after acceding, with the average lag being a decade (the United States is the exception, being a founder of the GATT in 1948 and being open no later than 1950 according to Sachs and Warner). Again, it seems that the GATT admitted closed countries and allowed them to remain closed for long periods of time (using the Sachs-Warner criteria). 
Others have also created liberalization dates; probably the most well-known were created by the World Bank (see Papageorgiou, Choksi and Michaely, 1990). The World Bank's liberalization dates are tabulated in Table 5, along with the dates of GATT membership. Of the 36 episodes of liberalization tabulated, two-thirds followed GATT accession, often with substantial lags. Four episodes preceded membership and eight coincided. The average lag between GATT accession and the onset of liberalization exceeds eight years (even including the cases where liberalization preceded accession).

Greenaway et al (2002) use two additional indicators of liberalization: 1) the date of a country's first "structural adjustment loan" from the World Bank, and 2) dates derived by a World Bank team from a set of indicators including tariffs, quotas, export distortions and exchange rates. In table $6 \mathrm{I}$ list both sets of liberalization dates along with GATT accession dates. These liberalization dates again usually lag GATT accessions, often dramatically. Indeed, the mean lag between accession and liberalization exceeds fifteen years for both measures of liberalization, and median lags are longer.

I conclude that there is no clear evidence that GATT accession or membership spurred trade liberalizations.

\section{Interpretation}

Perhaps the non-effect of GATT membership on trade is unsurprising. After all, the GATT built in a large number of devices to allow countries (technically "contracting parties") to pursue their own policies. For instance, article VI of the GATT allowed members to respond to dumping; article XII allowed a response for balance of payments considerations; article XVIII allowed protectionism for developing countries; there were opt-outs in articles XIX through XXI 
for a variety of reasons including public morals, health, security, and so forth; article XXXV allowed particular countries simply to ignore other members of the GATT; and there was a procedure to waive obligations in article $\mathrm{XXV}$. That is, there was plenty of room for countries to be in the GATT de jure without adhering to the spirit of the agreement. Jackson (1969) provides over two hundred pages of discussion on exceptions to GATT obligations; see also Dam (1970) and Curzon (1965). The WTO may be a much more serious beast; time will tell.

\section{Caveats and Outstanding Issues}

It would be nice to add more structure to the statistical model, which might deliver more convincing results. To do this, one needs to model the aggregate stance of trade policy directly. Most of the recent literature on endogenous protection is primarily concerned with the crossindustry incidence of protection, rather than its international or intertemporal nature, a fact noted in Rodrik's (1995) survey; see Trefler (1993), Grossman and Helpman (1994, 1995); Goldberg and Maggi (1999). Better instrumental variables are desirable and might be available with more structure.

It might be the case that the GATT/WTO has acted as an international provider of public goods in the form of global trade that is more liberal than it would have been in the absence of the system. That is, the GATT/WTO might matter, independent of its membership. In this case, GATT membership (which varies across both countries and time) might not be associated with more liberal trade policy (as I have found), but the very existence of the GATT has made trade more liberal. It is impossible to test this novel hypothesis.

Measurement error remains a serious problem in this literature, so conclusions should be cautious. Nevertheless, it is important to note that the measurement error here concerns the 
regressand, not an independent variable. This measurement error does not bias regression results, though it might weaken them. ${ }^{14}$

I have also tried, without success, to uncover relationships between GATT/WTO membership and combinations of measures of trade policy. I estimate the latter using factor analysis. Others may have more luck.

If - as seems consistent with much of the data - the GATT/WTO is not associated with more liberal trade policy, why does it exist? As noted by Staiger (1995), it may be that the organization simply coordinates trade policy without systematically liberalizing it for members. It may also serve a role as a disseminator of information or coordinate punishments; see Bagwell and Staiger $(1999,2000)$. This remains a good topic for future research. And of course a weak international institution may be the deliberate result of its members.

Finally, the question arises: If the GATT/WTO is not responsible for more liberal trade policy, what is freeing trade? An interesting and important question, though not the topic of this paper. Perhaps the movement away from tariffs has resulted from the gradual development of more efficient ways of raising government revenue, such as income and value-added taxes. The backlash against import substitution polices may also have resulted in more liberal trade policy; both trends are suggested by Rodrik (1995). In any case, Appendix 3 shows that there is a statistically significant trend in only one of the nine basic measures of trade policy for which panel data are available, once the effects of country size, income and remoteness are controlled. And that variable - the deviation of trade from that predicted by the gravity model - is an indirect measure of trade policy. ${ }^{15}$ 


\section{Conclusion}

In 1987, Indian tariff revenues reached $53 \%$ of import values. India had been a founding member of the GATT in 1948. Yet Indian tariffs revenues have never fallen below $20 \%$ of Indian imports, at least during the 25 years for which we have data. This from a measure of tariffs known to be biased down since highly taxed goods tend not to be imported! Comparable tariff data exist for 91 countries in 1987, at which time 89 countries had lower tariffs than India. 23 of these 89 countries were not members of the GATT; they had tariff rates averaging $15.7 \%$. GATT members collected tariffs averaging $11.4 \%$ (a figure that is statistically indistinguishable from that of outsiders at even the $10 \%$ level). Nor is there something special about 1987; average tariff rates have been insignificantly different for members and non-members for all years since the mid 1970s at the standard 5\% confidence level. Succinctly, tariff rates don't seem to be significantly different for GATT members and outsiders. Nor do other measures of trade policy.

In this short paper, I have used simple conventional statistical techniques to analyze the relationship between GATT/WTO membership and international trade policy. Despite my use of over sixty measures of trade policy, I have been unable to find convincing evidence that membership in the multilateral trade system is associated with more liberal trade policy. The exception is that members of the system usually enjoy slightly more economic freedom using the Heritage Foundation's index. There are almost no discernible differences between GATT/WTO members and non-members for tariff rates, measures of non-tariff barrier coverage, price-based measures, measures of openness, and so forth. Are we really so sure that the WTO has actually liberalized trade ... or is actually liberalizing it? 
Table 1: Measures of Trade Policy

\begin{tabular}{|c|c|c|c|}
\hline Measure & Data Source & Obs. & $\begin{array}{c}\text { \% GATT } \\
\text { /WTO }\end{array}$ \\
\hline \multicolumn{4}{|l|}{ Openness } \\
\hline (Exports+Imports)/GDP, 1950-1998 & PWT6 & 5541 & $62 \%$ \\
\hline Import Penetration: overall, 1985 & Pritchett & 97 & $71 \%$ \\
\hline Import Penetration: manufacturing, 1985 & Pritchett & 97 & $71 \%$ \\
\hline Import Penetration: agriculture, 1985 & Pritchett & 97 & $71 \%$ \\
\hline Import Penetration: resources, 1985 & Pritchett & 97 & $71 \%$ \\
\hline Import Penetration: overall, 1982 & Pritchett & 97 & $70 \%$ \\
\hline Import Penetration: manufacturing, 1982 & Pritchett & 97 & $70 \%$ \\
\hline Import Penetration: agriculture, 1982 & Pritchett & 97 & $70 \%$ \\
\hline Import Penetration: resources, 1982 & Pritchett & 97 & $70 \%$ \\
\hline TARS Trade Penetration: overall, 1985 & Pritchett & 97 & $71 \%$ \\
\hline TARS Trade Penetration: manuf., 1985 & Pritchett & 97 & $71 \%$ \\
\hline TARS Trade Penetration: agric., 1985 & Pritchett & 97 & $71 \%$ \\
\hline TARS Trade Penetration: res., 1985 & Pritchett & 97 & $71 \%$ \\
\hline TARS Trade Penetration: overall, 1982 & Pritchett & 95 & $70 \%$ \\
\hline TARS Trade Penetration: manuf., 1982 & Pritchett & 95 & $70 \%$ \\
\hline TARS Trade Penetration: agric., 1982 & Pritchett & 95 & $70 \%$ \\
\hline TARS Trade Penetration: res., 1982 & Pritchett & 95 & $70 \%$ \\
\hline \multicolumn{4}{|l|}{ Tariffs } \\
\hline Import Duties as \% imports, 1970-1998 & WDI & 2292 & $73 \%$ \\
\hline Tariffs on int. inputs and capital goods, $1980 \mathrm{~s}$ & Barro-Lee & 104 & $67 \%$ \\
\hline Trade Taxes/Trade, early $1980 \mathrm{~s}$ & Edwards & 55 & $79 \%$ \\
\hline Wght. Avg. Tot. Import Charges: overall, late 1980s & Pritchett & 81 & $63 \%$ \\
\hline Wght. Avg. Tot. Import Charges: manuf., late 1980s & Pritchett & 81 & $63 \%$ \\
\hline Wght. Avg. Tot. Import Charges: agric., late 1980s & Pritchett & 81 & $63 \%$ \\
\hline Wght. Avg. Tot. Import Charges: res., late 1980s & Pritchett & 81 & $63 \%$ \\
\hline Effective Rate of Protection, various & Heitger & 47 & $66 \%$ \\
\hline Std. Dev. of Eff. Rate of Protection, various & Heitger & 47 & $66 \%$ \\
\hline \multicolumn{4}{|l|}{ Non-Tariff Barriers } \\
\hline NTB frequency on int. inputs, K. goods, mid-late 1980s & Barro-Lee & 104 & $67 \%$ \\
\hline NTB Coverage: overall, 1987 & Pritchett & 81 & $63 \%$ \\
\hline NTB Coverage: manufacturing, 1987 & Pritchett & 81 & $63 \%$ \\
\hline NTB Coverage: agriculture, 1987 & Pritchett & 81 & $63 \%$ \\
\hline NTB Coverage: resources, 1987 & Pritchett & 81 & $63 \%$ \\
\hline \multicolumn{4}{|l|}{ Informal Measures } \\
\hline Trade Orientation 1963-73 & World Bank & 40 & $58 \%$ \\
\hline Trade Orientation 1973-85 & World Bank & 40 & $69 \%$ \\
\hline Trade Orientation Ranking 1975 & Edwards & 62 & $74 \%$ \\
\hline Trade Orientation Ranking 1985 & Edwards & 62 & $81 \%$ \\
\hline Heritage Foundation Index, & Edwards & 98 & $75 \%$ \\
\hline NBER Trade Liberalization Phase, late 1980s & Krueger & 229 & $57 \%$ \\
\hline Index Economic Freedom, 1995-98 & IEF & 523 & $78 \%$ \\
\hline Trade Policy Measure from IEF, 1995-98 & IEF & 523 & $78 \%$ \\
\hline \multicolumn{4}{|l|}{ Composite Measures } \\
\hline Sachs-Warner 1970s & Edwards & 63 & $70 \%$ \\
\hline Sachs-Warner 1980s & Edwards & 63 & $75 \%$ \\
\hline Index from FX and commercial policy, 1961-84 & Harrison & 356 & $82 \%$ \\
\hline Index from Tariffs and NTBs, $1978-88$ & Harrison & 255 & $85 \%$ \\
\hline Indirect counter-agricultural bias, 1961-86 & Harrison & 396 & $69 \%$ \\
\hline
\end{tabular}




\begin{tabular}{|l|c|r|r|}
\hline Measures based on Residuals & & & \\
\hline Leamer's Measure, 1982 & Edwards & 49 & $88 \%$ \\
\hline Leamers's openness: overall, 1982 & Pritchett & 44 & $86 \%$ \\
\hline Leamers's openness: manufacturing, 1982 & Pritchett & 44 & $86 \%$ \\
\hline Leamers's openness: agriculture, 1982 & Pritchett & 44 & $86 \%$ \\
\hline Leamers's openness: resources, 1982 & Pritchett & 44 & $86 \%$ \\
\hline Leamers's intervention measure: overall, 1982 & Pritchett & 44 & $86 \%$ \\
\hline Leamers's intervention measure: manuf., 1982 & Pritchett & 44 & $86 \%$ \\
\hline Leamers's intervention measure: ag. 1982 & Pritchett & 44 & $86 \%$ \\
\hline Leamers's intervention measure: res., 1982 & Pritchett & 44 & $86 \%$ \\
\hline Leamers's measure: overall, 1982 & Pritchett & 44 & $86 \%$ \\
\hline Leamers's measure: manufacturing, 1982 & Pritchett & 44 & $86 \%$ \\
\hline Leamers's measure: agriculture, 1982 & Pritchett & 44 & $86 \%$ \\
\hline Leamers's measure: resources, 1982 & Pritchett & 44 & $86 \%$ \\
\hline Gravity-Residuals, basic model, 1960-92 & Hiscox-Kastner & 2574 & $69 \%$ \\
\hline Gravity-Residuals, augmented model, 1960-92 & Hiscox-Kastner & 2574 & $69 \%$ \\
\hline Price-Based Measures & & & \\
\hline Distortion Index, 1990 & Pritchett & 93 & $83 \%$ \\
\hline Variability Index, 1990 & Pritchett & 93 & $83 \%$ \\
\hline Movement to International Prices, 1961-87 & Harrison & 539 & $61 \%$ \\
\hline Modified Price Distortion Index, 1961-87 & Harrison & 729 & $54 \%$ \\
\hline Black Market Premium, 1961-89 & Harrison & 1463 & $65 \%$ \\
\hline
\end{tabular}


Table 2: Trade Policy and GATT/WTO membership

Cross-Sectional Measures of Trade Policy

\begin{tabular}{|c|c|c|c|}
\hline Dependent Variable & $\begin{array}{c}\text { OLS } \\
\text { Bivariate } \\
\text { Regression } \\
\text { Coefficient }\end{array}$ & $\begin{array}{c}\text { OLS } \\
\text { Augmented } \\
\text { Regression } \\
\text { Coefficient }\end{array}$ & $\begin{array}{c}\text { IV } \\
\text { Bivariate } \\
\text { Regression } \\
\text { Coefficient }\end{array}$ \\
\hline \multicolumn{4}{|l|}{ Openness } \\
\hline Import Penetration: overall & $\begin{array}{c}-2.4 \\
(.5)\end{array}$ & $\begin{array}{l}1.3 \\
(.3)\end{array}$ & $\begin{array}{l}12 . \\
(.7)\end{array}$ \\
\hline Import Penetration: manufacturing & $\begin{array}{l}-2.6 \\
(.8)\end{array}$ & $\begin{array}{l}.5 \\
(.2)\end{array}$ & $\begin{array}{l}5.5 \\
(.5)\end{array}$ \\
\hline Import Penetration: agriculture & $\begin{array}{c}-.6 \\
(.8)\end{array}$ & $\begin{array}{l}-.2 \\
(.2)\end{array}$ & $\begin{array}{l}.1 \\
(.0)\end{array}$ \\
\hline Import Penetration: resources & $\begin{array}{l}1.1 \\
(.8)\end{array}$ & $\begin{array}{c}2.0 \\
(1.5)\end{array}$ & $\begin{array}{c}6.7 \\
(1.2) \\
\end{array}$ \\
\hline Import Penetration: overall & $\begin{array}{c}-5.9 \\
(1.1) \\
\end{array}$ & $\begin{array}{l}2.2 \\
(.4)\end{array}$ & $\begin{array}{l}-.7 \\
(.0) \\
\end{array}$ \\
\hline Import Penetration: manufacturing & $\begin{array}{l}-3.9 \\
(1.3) \\
\end{array}$ & $\begin{array}{l}-.4 \\
(.1) \\
\end{array}$ & $\begin{array}{l}-.3 \\
(.0) \\
\end{array}$ \\
\hline Import Penetration: agriculture & $\begin{array}{l}-1.1 \\
(1.4) \\
\end{array}$ & $\begin{array}{l}-.4 \\
(.5)\end{array}$ & $\begin{array}{l}-.3 \\
(.1) \\
\end{array}$ \\
\hline Import Penetration: resources & $\begin{array}{l}-.9 \\
(.4)\end{array}$ & $\begin{array}{c}2.9 \\
(1.5) \\
\end{array}$ & $\begin{array}{l}-.6 \\
(.1) \\
\end{array}$ \\
\hline TARS Trade Penetration: overall & $\begin{array}{l}-1.5 \\
(.2)\end{array}$ & $\begin{array}{l}6.2 \\
(.9)\end{array}$ & $\begin{array}{l}26 . \\
(.8)\end{array}$ \\
\hline TARS Trade Penetration: manuf. & $\begin{array}{l}1.9 \\
(.4)\end{array}$ & $\begin{array}{l}3.0 \\
(.6)\end{array}$ & $\begin{array}{c}41 \\
(1.7)\end{array}$ \\
\hline TARS Trade Penetration: agric. & $\begin{array}{c}.4 \\
(.2)\end{array}$ & $\begin{array}{l}1.1 \\
(.7)\end{array}$ & $\begin{array}{l}6.5 \\
(.8)\end{array}$ \\
\hline TARS Trade Penetration: res. & $\begin{array}{l}-3.7 \\
(.9) \\
\end{array}$ & $\begin{array}{l}1.8 \\
(.7) \\
\end{array}$ & $\begin{array}{c}-23 . \\
(1.4) \\
\end{array}$ \\
\hline TARS Trade Penetration: overall & $\begin{array}{c}-32 . \\
(1.2) \\
\end{array}$ & $\begin{array}{l}5.1 \\
(.6) \\
\end{array}$ & $\begin{array}{l}29 . \\
(.8) \\
\end{array}$ \\
\hline TARS Trade Penetration: manuf. & $\begin{array}{l}-6.7 \\
(.9) \\
\end{array}$ & $\begin{array}{l}2.1 \\
(.4) \\
\end{array}$ & $\begin{array}{c}32 . \\
(1.5) \\
\end{array}$ \\
\hline TARS Trade Penetration: agric. & \begin{tabular}{|l|}
-3.9 \\
$(1.4)$ \\
\end{tabular} & $\begin{array}{c}.0 \\
(.0)\end{array}$ & $\begin{array}{l}6.5 \\
(.7) \\
\end{array}$ \\
\hline TARS Trade Penetration: res. & $\begin{array}{l}-20.9 \\
(1.1) \\
\end{array}$ & $\begin{array}{l}2.5 \\
(.7) \\
\end{array}$ & $\begin{array}{l}-10 . \\
(.6)\end{array}$ \\
\hline \multicolumn{4}{|l|}{ Tariffs and Trade Taxes } \\
\hline Tariffs on int. inputs and capital goods & $\begin{array}{c}.0 \\
(.1) \\
\end{array}$ & $\begin{array}{c}.0 \\
(.4) \\
\end{array}$ & $\begin{array}{c}-.2 \\
(1.3) \\
\end{array}$ \\
\hline Trade Taxes/Trade & $\begin{array}{c}-.02 \\
(1.3) \\
\end{array}$ & $\begin{array}{l}-.01 \\
(.8) \\
\end{array}$ & $\begin{array}{l}-.13^{*} \\
(2.1) \\
\end{array}$ \\
\hline Wght. Avg. Tot. Import Charges: overall & $\begin{array}{c}6.7 \\
(1.4) \\
\end{array}$ & $\begin{array}{l}2.3 \\
(.5) \\
\end{array}$ & $\begin{array}{l}481 . \\
(.2)\end{array}$ \\
\hline Wght. Avg. Tot. Import Charges: manuf. & $\begin{array}{c}7.2 \\
(1.4) \\
\end{array}$ & $\begin{array}{l}2.5 \\
(.5) \\
\end{array}$ & $\begin{array}{l}517 \\
(.2) \\
\end{array}$ \\
\hline Wght. Avg. Tot. Import Charges: agric. & $\begin{array}{c}5.4 \\
(1.1) \\
\end{array}$ & $\begin{array}{c}.8 \\
(.2) \\
\end{array}$ & $\begin{array}{l}401 \\
(.2) \\
\end{array}$ \\
\hline Wght. Avg. Tot. Import Charges: res. & $\begin{array}{c}5.7 \\
(1.4) \\
\end{array}$ & $\begin{array}{l}3.2 \\
(.7) \\
\end{array}$ & $\begin{array}{l}351 \\
(.2) \\
\end{array}$ \\
\hline Effective Rate of Protection & $\begin{array}{c}32 . \\
(1.3) \\
\end{array}$ & $\begin{array}{l}69 . * \\
(2.3) \\
\end{array}$ & $\begin{array}{l}-119 \\
(1.0) \\
\end{array}$ \\
\hline Std. Dev. of Eff. Rate of Protection & $\begin{array}{l}29 . \\
(.9) \\
\end{array}$ & $\begin{array}{c}75 . \\
(1.8) \\
\end{array}$ & $\begin{array}{r}-150 . \\
(1.0) \\
\end{array}$ \\
\hline
\end{tabular}




\begin{tabular}{|c|c|c|c|}
\hline Dependent Variable & $\begin{array}{c}c \text { OLS } \\
\text { Bivariate } \\
\text { Regression } \\
\text { Coefficient } \\
\end{array}$ & $\begin{array}{c}\text { OLS } \\
\text { Augmented } \\
\text { Regression } \\
\text { Coefficient } \\
\end{array}$ & $\begin{array}{c}\text { IV } \\
\text { Bivariate } \\
\text { Regression } \\
\text { Coefficient } \\
\end{array}$ \\
\hline \multicolumn{4}{|l|}{ Non-Tariff Barriers } \\
\hline NTB frequency on int. inputs, K. goods & $\begin{array}{c}.1 \\
(.2) \\
\end{array}$ & $\begin{array}{l}-.0 \\
(.5) \\
\end{array}$ & $\begin{array}{l}-.0 \\
(.2) \\
\end{array}$ \\
\hline NTB Coverage: overall & $\begin{array}{c}10 . \\
(1.1)\end{array}$ & $\begin{array}{c}.9 \\
(.1)\end{array}$ & $\begin{array}{c}-3098 \\
(.1)\end{array}$ \\
\hline NTB Coverage: manufacturing & $\begin{array}{c}8.9 \\
(1.0) \\
\end{array}$ & $\begin{array}{c}.4 \\
(.1)\end{array}$ & $\begin{array}{c}-3073 \\
(.1)\end{array}$ \\
\hline NTB Coverage: agriculture & $\begin{array}{l}6.3 \\
(.7) \\
\end{array}$ & $\begin{array}{c}-4.8 \\
(.7) \\
\end{array}$ & $\begin{array}{c}-3063 \\
(.1) \\
\end{array}$ \\
\hline NTB Coverage: resources & $\begin{array}{c}19 . \\
(1.8)\end{array}$ & $\begin{array}{l}9.7 \\
(.9)\end{array}$ & $\begin{array}{c}-3102 \\
(.1)\end{array}$ \\
\hline \multicolumn{4}{|l|}{ Informal Measures } \\
\hline Trade Orientation 1963-73 & $\begin{array}{c}.5 \\
(1.5) \\
\end{array}$ & $\begin{array}{c}.4 \\
(1.2) \\
\end{array}$ & $\begin{array}{l}62 . \\
(.0) \\
\end{array}$ \\
\hline Trade Orientation 1973-85 & $\begin{array}{c}0 . \\
(.0)\end{array}$ & $\begin{array}{l}-.1 \\
(.4)\end{array}$ & $\begin{array}{l}16 . \\
(.1)\end{array}$ \\
\hline Trade Orientation Ranking 1975 & $\begin{array}{l}3.6 \\
(.5) \\
\end{array}$ & $\begin{array}{l}3.0 \\
(.5) \\
\end{array}$ & $\begin{array}{l}-6.1 \\
(.3) \\
\end{array}$ \\
\hline Trade Orientation Ranking 1985 & $\begin{array}{l}2.5 \\
(.3)\end{array}$ & $\begin{array}{l}-2.5 \\
(.4)\end{array}$ & $\begin{array}{l}-34 . \\
(.8)\end{array}$ \\
\hline Heritage Foundation Index & $\begin{array}{l}.7 * * \\
(3.2) \\
\end{array}$ & $\begin{array}{c}-.3 \\
(1.2) \\
\end{array}$ & $\begin{array}{c}-7.6^{*} \\
(2.0) \\
\end{array}$ \\
\hline \multicolumn{4}{|l|}{ Composite Measures } \\
\hline Sachs-Warner 1970s & $\begin{array}{c}.0 \\
(.1)\end{array}$ & $\begin{array}{c}-.2 \\
(1.2) \\
\end{array}$ & $\begin{array}{l}1.3^{*} \\
(2.4) \\
\end{array}$ \\
\hline Sachs-Warner 1980s & $\begin{array}{c}.0 \\
(.4) \\
\end{array}$ & $\begin{array}{c}-.1 \\
(.9) \\
\end{array}$ & $\begin{array}{c}1.8 \\
(1.9) \\
\end{array}$ \\
\hline \multicolumn{4}{|l|}{ Measures based on Residuals } \\
\hline Leamer's Measure & $\begin{array}{l}.7 * * \\
(2.7)\end{array}$ & $\begin{array}{c}.2 \\
(1 .)\end{array}$ & $\begin{array}{c}1.7 \\
(1.1) \\
\end{array}$ \\
\hline Leamers's openness: overall & $\begin{array}{l}-.0 \\
(.2)\end{array}$ & $\begin{array}{c}.0 \\
(.1)\end{array}$ & $\begin{array}{l}-2.3 \\
(.2)\end{array}$ \\
\hline Leamers's openness: manufacturing & $\begin{array}{l}.0 \\
(.3)\end{array}$ & $\begin{array}{l}-0 \\
(.3)\end{array}$ & $\begin{array}{l}-1.8 \\
(.2)\end{array}$ \\
\hline Leamers's openness: agriculture & $\begin{array}{c}-.0 \\
(.8) \\
\end{array}$ & $\begin{array}{c}-.0 \\
(.3) \\
\end{array}$ & $\begin{array}{l}-1.2 \\
(.2) \\
\end{array}$ \\
\hline Leamers's openness: resources & $\begin{array}{c}.0 \\
(1.6) \\
\end{array}$ & $\begin{array}{c}.0 \\
(1.5) \\
\end{array}$ & $\begin{array}{c}.6 \\
(.2) \\
\end{array}$ \\
\hline Leamers's intervention measure: overall & $\begin{array}{c}-.1 \\
(1.0) \\
\end{array}$ & $\begin{array}{c}-.0 \\
(.1) \\
\end{array}$ & $\begin{array}{l}-6 \\
(.2) \\
\end{array}$ \\
\hline Leamers's intervention measure: manuf. & $\begin{array}{l}-.0 \\
(.8) \\
\end{array}$ & $\begin{array}{c}-.0 \\
(.6) \\
\end{array}$ & $\begin{array}{c}-.8 \\
(.2) \\
\end{array}$ \\
\hline Leamers's intervention measure: ag. & $\begin{array}{c}-.03 \\
(1.0)\end{array}$ & $\begin{array}{l}.0 \\
(.2)\end{array}$ & $\begin{array}{l}.5 \\
(.2)\end{array}$ \\
\hline Leamers's intervention measure: res. & $\begin{array}{l}-.01 \\
(.5) \\
\end{array}$ & $\begin{array}{c}.0 \\
(.5) \\
\end{array}$ & $\begin{array}{l}-.3 \\
(.2) \\
\end{array}$ \\
\hline Leamers's measure: overall & $\begin{array}{c}-.1 \\
(.3) \\
\end{array}$ & $\begin{array}{c}-.3 \\
(.9) \\
\end{array}$ & $\begin{array}{l}-22 . \\
(.2) \\
\end{array}$ \\
\hline Leamers's measure: manufacturing & $\begin{array}{c}-.2 \\
(.3) \\
\end{array}$ & $\begin{array}{l}-.6 \\
(.9) \\
\end{array}$ & $\begin{array}{l}-34 . \\
(.2)\end{array}$ \\
\hline Leamers's measure: agriculture & $\begin{array}{c}-.1 \\
(.2) \\
\end{array}$ & $\begin{array}{c}-.2 \\
(.7) \\
\end{array}$ & $\begin{array}{l}-22 . \\
(.2) \\
\end{array}$ \\
\hline Leamers's measure: resources & $\begin{array}{c}-.0 \\
(.1) \\
\end{array}$ & $\begin{array}{c}-.0 \\
(.2) \\
\end{array}$ & $\begin{array}{c}-9.1 \\
(.2) \\
\end{array}$ \\
\hline
\end{tabular}




\begin{tabular}{|l|c|c|c|}
\hline Dependent Variable & $\begin{array}{c}\text { OLS } \\
\text { Bivariate } \\
\text { Regression } \\
\text { Coefficient }\end{array}$ & $\begin{array}{c}\text { OLS } \\
\text { Augmented } \\
\text { Regression } \\
\text { Coefficient }\end{array}$ & $\begin{array}{c}\text { IV } \\
\text { Bivariate } \\
\text { Regression } \\
\text { Coefficient }\end{array}$ \\
\hline Price-Based Measures & & & \\
\hline Distortion Index & -2.8 & 8.1 & -321 \\
& $(.3)$ & $(.8)$ & $(1.6)$ \\
\hline Variability Index & -.03 & -.02 & -.13 \\
& $(1.4)$ & $(.6)$ & $(.9)$ \\
\hline
\end{tabular}

Independent variable is membership in GATT/WTO.

Instrumental variable is polity score.

Augmenting regressors: $\log$ (population); $\log ($ real GDP p/c); and remoteness. Absolute t-statistics (computed with robust standard errors) in parentheses.

** indicates significance at $1 \%$; at $5 \%$. 
Table 3: Trade Policy and GATT/WTO membership: Panel Measures

\begin{tabular}{|c|c|c|c|c|c|c|c|c|}
\hline OLS & $\begin{array}{l}\text { Bivariate } \\
\text { Regression } \\
\text { Coefficient }\end{array}$ & $\begin{array}{c}\text { Year } \\
\text { Effects }\end{array}$ & $\begin{array}{l}\text { Country } \\
\text { Effects }\end{array}$ & $\begin{array}{c}\text { Year and } \\
\text { Country } \\
\text { Effects }\end{array}$ & $\begin{array}{l}\text { Augmented } \\
\text { Regression } \\
\text { Coefficient }\end{array}$ & $\begin{array}{c}\text { Year } \\
\text { Effects }\end{array}$ & $\begin{array}{l}\text { Country } \\
\text { Effects }\end{array}$ & $\begin{array}{c}\text { Year and } \\
\text { Country } \\
\text { Effects }\end{array}$ \\
\hline (Exports+Imports)/GDP & $\begin{array}{l}.6 \\
(.1)\end{array}$ & $\begin{array}{l}-5.0 \\
(1.1)\end{array}$ & $\begin{array}{c}17.0^{* * *} \\
(5.3)\end{array}$ & $\begin{array}{c}5.3 \\
(1.6)\end{array}$ & $\begin{array}{l}2.3 \\
(.6)\end{array}$ & $\begin{array}{l}-.1 \\
(.0)\end{array}$ & $\begin{array}{c}4.7 \\
(1.6)\end{array}$ & $\begin{array}{c}5.3 \\
(1.7)\end{array}$ \\
\hline Import Duties as \% imports & $\begin{array}{l}-7.8 \\
(1.6)\end{array}$ & $\begin{array}{l}-7.5 \\
(1.6)\end{array}$ & $\begin{array}{l}-.3 \\
(.4)\end{array}$ & $\begin{array}{c}2.1 \\
(1.7)\end{array}$ & $\begin{array}{l}-.2 \\
(.1)\end{array}$ & $\begin{array}{l}-.2 \\
(.2)\end{array}$ & $\begin{array}{l}1.3 \\
(1.3)\end{array}$ & $\begin{array}{c}1.8 \\
(1.8)\end{array}$ \\
\hline $\begin{array}{l}\text { NBER Trade Liberalization } \\
\text { Phase }\end{array}$ & $\begin{array}{l}.2 \\
(.5)\end{array}$ & $\begin{array}{l}.0 \\
(.0)\end{array}$ & $\begin{array}{l}.6 \\
.7\end{array}$ & $\begin{array}{c}.2 \\
(.3)\end{array}$ & $\begin{array}{l}.2 \\
(.5)\end{array}$ & $\begin{array}{l}.1 \\
(.4)\end{array}$ & $\begin{array}{l}.0 \\
(.1)\end{array}$ & $\begin{array}{c}-.5 \\
(1.0)\end{array}$ \\
\hline Index Economic Freedom & $\begin{array}{l}-.5^{* *} \\
(3.9)\end{array}$ & $\begin{array}{l}-.5^{* *} \\
(3.9)\end{array}$ & $\begin{array}{l}-.1 \\
(1.1)\end{array}$ & $\begin{array}{l}-.0 \\
(.2)\end{array}$ & $\begin{array}{l}-.4^{* *} \\
(3.6)\end{array}$ & $\begin{array}{l}-.4 * * \\
(3.5)\end{array}$ & $\begin{array}{l}-.0 \\
(.2)\end{array}$ & $\begin{array}{c}.0 \\
(.0)\end{array}$ \\
\hline $\begin{array}{l}\text { Trade Policy Measure from } \\
\text { IEF }\end{array}$ & $\begin{array}{l}-.5^{*} \\
(2.3)\end{array}$ & $\begin{array}{l}-.5^{*} \\
(2.3)\end{array}$ & $\begin{array}{l}-.9 \\
(1.5)\end{array}$ & $\begin{array}{c}-.7 \\
(1.1)\end{array}$ & $\begin{array}{c}-.3 \\
(1.3)\end{array}$ & $\begin{array}{c}-.2 \\
(1.3)\end{array}$ & $\begin{array}{l}-.2 \\
(.9)\end{array}$ & $\begin{array}{l}-.1 \\
(.2)\end{array}$ \\
\hline $\begin{array}{l}\text { Index from FX and } \\
\text { commercial policy }\end{array}$ & $\begin{array}{l}-.00 \\
(.3)\end{array}$ & $\begin{array}{l}-.01 \\
(1.5)\end{array}$ & $\begin{array}{c}.02 \\
(1.8)\end{array}$ & $\begin{array}{l}.00 \\
(.0)\end{array}$ & $\begin{array}{l}-.01 \\
(.5)\end{array}$ & $\begin{array}{l}-.01 \\
(1.2)\end{array}$ & $\begin{array}{l}.00 \\
(.2)\end{array}$ & $\begin{array}{l}.00 \\
(.1)\end{array}$ \\
\hline Index from Tariffs and NTBs & $\begin{array}{c}.2 \\
(1.3)\end{array}$ & $\begin{array}{l}.1 \\
(.4)\end{array}$ & $\begin{array}{l}9 * * \\
(3.5)\end{array}$ & $\begin{array}{c}.5 \\
(1.8)\end{array}$ & $\begin{array}{l}.6^{*} \\
(2.2)\end{array}$ & $\begin{array}{c}.5 \\
(1.6)\end{array}$ & $\begin{array}{c}.4^{*} \\
(2.0)\end{array}$ & $\begin{array}{c}4^{*} \\
(2.0)\end{array}$ \\
\hline $\begin{array}{l}\text { Indirect counter-agricultural } \\
\text { bias }\end{array}$ & $\begin{array}{c}-.0004 \\
(.9)\end{array}$ & $\begin{array}{c}-.0003 \\
(.6)\end{array}$ & $\begin{array}{c}-.0001 \\
(.3)\end{array}$ & $\begin{array}{c}.0002 \\
(.6)\end{array}$ & $\begin{array}{c}-.0006 \\
(1.6)\end{array}$ & $\begin{array}{c}-.0005 \\
(1.3)\end{array}$ & $\begin{array}{c}.0001 \\
(.4)\end{array}$ & $\begin{array}{c}.0001 \\
(.4)\end{array}$ \\
\hline $\begin{array}{l}\text { Gravity-Residuals, basic } \\
\text { model }\end{array}$ & $\begin{array}{l}-2.9 \\
(1.4)\end{array}$ & $\begin{array}{l}-3.7 \\
(1.7)\end{array}$ & $\begin{array}{l}1.5 \\
(1.6)\end{array}$ & $\begin{array}{l}-1.8 \\
(1.8)\end{array}$ & $\begin{array}{c}-1.3 \\
(.9)\end{array}$ & $\begin{array}{l}-1.7 \\
(1.2)\end{array}$ & $\begin{array}{l}-1.8 \\
(1.9)\end{array}$ & $\begin{array}{l}-1.8 \\
(1.9)\end{array}$ \\
\hline $\begin{array}{l}\text { Gravity-Residuals, } \\
\text { augmented model }\end{array}$ & $\begin{array}{l}-2.3 \\
(1.2)\end{array}$ & $\begin{array}{l}-3.3 \\
(1.6)\end{array}$ & $\begin{array}{l}2.6^{* *} \\
(2.9)\end{array}$ & $\begin{array}{l}-1.5 \\
(1.7)\end{array}$ & $\begin{array}{l}-.8 \\
(.6)\end{array}$ & $\begin{array}{l}-1.3 \\
(1.0)\end{array}$ & $\begin{array}{l}-1.6 \\
(1.7)\end{array}$ & $\begin{array}{l}-1.6 \\
(1.7)\end{array}$ \\
\hline $\begin{array}{l}\text { Movement to International } \\
\text { Prices }\end{array}$ & $\begin{array}{l}.01 \\
(.6)\end{array}$ & $\begin{array}{l}.02 \\
(1.3)\end{array}$ & $\begin{array}{l}-.01 \\
(.5)\end{array}$ & $\begin{array}{l}.01 \\
(.4)\end{array}$ & $\begin{array}{c}.01 \\
(1.2)\end{array}$ & $\begin{array}{c}.01 \\
(1.4)\end{array}$ & $\begin{array}{l}.02 \\
(.7)\end{array}$ & $\begin{array}{l}.01 \\
(.5)\end{array}$ \\
\hline $\begin{array}{l}\text { Modified Price Distortion } \\
\text { Index }\end{array}$ & $\begin{array}{l}-.04 \\
(1.2)\end{array}$ & $\begin{array}{l}-.05 \\
(1.2)\end{array}$ & $\begin{array}{l}-.01 \\
(.2)\end{array}$ & $\begin{array}{l}-.01 \\
(.3)\end{array}$ & $\begin{array}{l}-.03 \\
(.9)\end{array}$ & $\begin{array}{l}-.02 \\
(.5)\end{array}$ & $\begin{array}{l}-.02 \\
(.7)\end{array}$ & $\begin{array}{l}-.01 \\
(.3)\end{array}$ \\
\hline Black Market Premium & $\begin{array}{l}.01 \\
(.2)\end{array}$ & $\begin{array}{l}.01 \\
(.2)\end{array}$ & $\begin{array}{l}-.16 \\
(1.4)\end{array}$ & $\begin{array}{l}-.26 \\
(1.8)\end{array}$ & $\begin{array}{l}.03 \\
(.4)\end{array}$ & $\begin{array}{l}.02 \\
(.3)\end{array}$ & $\begin{array}{l}-.18 \\
(1.7)\end{array}$ & $\begin{array}{l}-.15 \\
(1.5)\end{array}$ \\
\hline
\end{tabular}

\begin{tabular}{|l|c|c|c|c|}
\hline IV & $\begin{array}{c}\text { Bivariate } \\
\text { Regression } \\
\text { Coefficient }\end{array}$ & $\begin{array}{c}\text { Year } \\
\text { Effects }\end{array}$ & $\begin{array}{c}\text { Country } \\
\text { Effects }\end{array}$ & $\begin{array}{c}\text { Year and } \\
\text { Country } \\
\text { Effects }\end{array}$ \\
\hline (Exports+Imports)/GDP & $39^{*}$ & 33 & $38^{* *}$ & -13 \\
& $(2.0)$ & $(1.9)$ & $(3.4)$ & $(.5)$ \\
\hline Import Duties as \% imports & $-34^{*}$ & $-32^{* *}$ & -14 & -45 \\
& $(2.4)$ & $(2.7)$ & $(1.0)$ & $(.9)$ \\
\hline NBER Trade Liberalization & .8 & 1.1 & -22 & -2.7 \\
Phase & $(.4)$ & $(.6)$ & $(.4)$ & $(.3)$ \\
\hline Index Economic Freedom & $-2.5^{* *}$ & $-2.5^{* *}$ & $-27^{*}$ & -4.6 \\
& $(3.6)$ & $(5.6)$ & $(2.0)$ & $(1.7)$ \\
\hline Trade Policy Measure from & $-4.4^{* *}$ & $-4.4^{* *}$ & -113 & -18 \\
IEF & $(3.4)$ & $(6.2)$ & $(1.8)$ & $(1.6)$ \\
\hline Index from FX and & .16 & .15 & .21 & .26 \\
commercial policy & $(.5)$ & $(.6)$ & $(1.7)$ & $(.6)$ \\
\hline Index from Tariffs and NTBs & -2.9 & -3.4 & 1.4 & -4.3 \\
& $(.3)$ & $(.6)$ & $(.2)$ & $(.4)$ \\
\hline Indirect counter-agricultural & -.003 & -.002 & .004 & .010 \\
bias & $.4)$ & $(.6)$ & $(.6)$ & $(1.0)$ \\
\hline Gravity-Residuals, basic & $-19^{* *}$ & $-22^{* *}$ & 26 & -117 \\
model & $(2.8)$ & $(3.3)$ & $(1.4)$ & $(.2)$ \\
\hline Gravity-Residuals, & $-18^{* *}$ & $-20^{* *}$ & 26 & -122 \\
augmented model & $(2.7)$ & $(3.2)$ & $(1.5)$ & $(.3)$ \\
\hline Movement to International & .12 & .13 & .06 & .06 \\
Prices & $(.5)$ & $(1.0)$ & $(.2)$ & $(.2)$ \\
\hline Modified Price Distortion & -.21 & -.12 & -1.3 & -3.4 \\
Index & $(.4)$ & $(.3)$ & $(1.2)$ & $(1.5)$ \\
\hline Black Market Premium & -.9 & -.9 & $-84^{*}$ & -13 \\
& $(.5)$ & $(1.3)$ & $(2.1)$ & $(1.9)$ \\
\hline
\end{tabular}

Independent variable is membership in GATT/WTO.

Augmenting regressors: $\log$ (population); $\log ($ real GDP p/c); and remoteness.

Absolute t-statistics (computed with standard errors robust to clustering by countries) in parentheses, except for IV estimates which use conventional standard errors.

$* *$ indicates significance at $1 \%$; at $5 \%$. 
Table 4a: Sachs and Warner's Closed Developing Economies and GATT/WTO membership

\section{Countries in GATT/WTO (date of accession)}

\begin{tabular}{|l|l|l|l|}
\hline Angola (1994) & Cote d'Ivoire (1963) & Mauritania (1963) & Rwanda (1966) \\
\hline Bangladesh (1972) & Dom. Rep. (1950) & Mozambique (1992) & Senegal (1963) \\
\hline Burkina Faso (1983) & Egypt (1970) & Myanmar (1948) & Sierra Leone (1961) \\
\hline Burundi (1965) & Gabon (1963) & Niger (1963) & Tanzania (1961) \\
\hline Cent. Afr. Rep. (1963) & Haiti (1950) & Nigeria (1960) & Togo (1964) \\
\hline Chad (1963) & Madagascar (1963) & Pakistan (1948) & Zaire (1971) \\
\hline Congo (1963) & Malawi (1964) & Pap. N. Guinea (1994) & Zimbabwe (1948) \\
\hline
\end{tabular}

\section{Countries outside GATT/WTO}

\begin{tabular}{|l|l|l|l|}
\hline Algeria* & Ethiopia & Iraq & Syria** \\
\hline China & Iran & Somalia & \\
\hline
\end{tabular}

*Algeria was formally a de facto GATT member from at least 1971.

** Syria liberalized 1951-1965

Table 4b: Sachs and Warner's Developed Economies with Year of Opening and year of GATT/WTO membership

\begin{tabular}{|c|c|c|c|c|c|c|c|c|}
\hline & Opened & Joined & & Opened & Joined & & Opened & Joined \\
\hline Australia & 1966 & 1948 & Israel & 1985 & 1962 & Sweden & 1960 & 1950 \\
\hline Austria & 1960 & 1951 & Italy & 1959 & 1950 & Switzerland & $\begin{array}{l}1950 \\
\text { latest }\end{array}$ & 1966 \\
\hline Belgium & 1960 & 1948 & Japan & 1962 & 1955 & $\begin{array}{l}\text { Trinidad \& } \\
\text { Tobago }\end{array}$ & Closed & 1962 \\
\hline Canada & 1952 & 1948 & Luxembourg & 1959 & 1948 & UK & 1960 & 1948 \\
\hline Denmark & 1960 & 1950 & Netherlands & 1959 & 1948 & USA & $\begin{array}{l}1950 \\
\text { latest } \\
\end{array}$ & 1948 \\
\hline Finland & 1960 & 1950 & New Zealand & 1986 & 1948 & Venezuela & Closed* & 1990 \\
\hline France & 1959 & 1948 & Norway & 1960 & 1948 & & & \\
\hline Germany & 1959 & 1951 & Spain & 1960 & 1963 & & & \\
\hline
\end{tabular}

* Venezuela was temporarily liberalized in 1950-59 and 1989-92.

Taken from Tables 3 and 4 of Sachs and Warner (1995). 
Table 5: World Bank Liberalization Dates and GATT Membership

\begin{tabular}{|l|c|c|l|l|l|l|c|c|}
\hline Argentina 1 & $1967-70$ & 1967 & Korea 1 & $1965-67$ & 1967 & Greece 1 & $1953-55$ & 1950 \\
\hline Argentina 2 & $1976-80$ & & Korea 2 & $1978-79$ & & Grece 2 & $1962-82$ & \\
\hline Brazil & $1965-73$ & 1948 & New Zealand 1 & $1951-56$ & 1948 & Israel 1 & $1952-55$ & 1962 \\
\hline Chile 1 & $1956-61$ & 1949 & New Zealand 2 & $1962-81$ & & Israel 2 & $1962-68$ & \\
\hline Chile 2 & $1974-81$ & & New Zealand 3 & $1982-84$ & & Israel 3 & $1969-77$ & \\
\hline Colombia 1 & $1964-66$ & 1981 & Pakistan 1 & $1959-65$ & 1948 & Portugal 1 & $1970-74$ & 1962 \\
\hline Colombia 2 & $1968-82$ & & Pakistan 2 & $1972-78$ & & Portugal 2 & $1977-80$ & \\
\hline Peru & $1979-80$ & 1951 & Philippines 1 & $1960-65$ & 1979 & Spain 1 & $1960-66$ & 1963 \\
\hline Uruguay & $1974-82$ & 1953 & Philippines 2 & $1970-74$ & & Spain 2 & $1970-74$ & \\
\hline Indonesia 1 & $1950-51$ & 1950 & Singapore & $1968-73$ & 1973 & Spain 3 & $1977-80$ & \\
\hline Indonesia 2 & $1966-72$ & & Sri Lanka 1 & $1968-70$ & 1948 & Turkey 1 & $1970-73$ & 1951 \\
\hline Yugoslavia & $1965-67$ & 1966 & Sri Lanka 2 & $1977-79$ & & Turkey 2 & $1980-84$ & \\
\hline
\end{tabular}

Taken from Table 1 "Episodes of Trade Liberalization" by Papageorgiou et. al.

Table 6: GATT Membership and Liberalization Dates from Greenaway et al.

\begin{tabular}{|l|c|c|c|l|c|c|c|l|c|c|c|}
\hline & $\begin{array}{c}\text { SA } \\
\text { loan }\end{array}$ & $\begin{array}{c}\text { Dean } \\
\text { Lib'n }\end{array}$ & $\begin{array}{c}\text { GATT } \\
\text { Entry }\end{array}$ & & $\begin{array}{c}\text { SA } \\
\text { loan }\end{array}$ & $\begin{array}{c}\text { Dean } \\
\text { Lib’n }\end{array}$ & $\begin{array}{c}\text { GATT } \\
\text { Entry }\end{array}$ & & $\begin{array}{c}\text { SA } \\
\text { loan }\end{array}$ & $\begin{array}{c}\text { Dean } \\
\text { Lib’n }\end{array}$ & $\begin{array}{c}\text { GATT } \\
\text { Entry }\end{array}$ \\
\hline Algeria & 1989 & & & Honduras & 1988 & & 1994 & Philippines & 1980 & 1986 & 1979 \\
\hline Argentina & 1987 & 1989 & 1967 & India & 1991 & & 1948 & Senegal & 1981 & 1986 & 1963 \\
\hline Bangladesh & 1989 & & 1972 & Indonesia & 1987 & 1986 & 1950 & South Africa & & 1990 & 1948 \\
\hline Bolivia & 1980 & & 1990 & Jamaica & 1982 & & 1963 & Sri Lanka & & 1987 & 1948 \\
\hline Brazil & 1983 & 1987 & 1948 & Kenya & 1980 & 1988 & 1964 & Thailand & 1982 & 1989 & 1982 \\
\hline C.A.R. & 1987 & & 1963 & Korea & 1982 & 1987 & 1967 & Togo & 1983 & & 1964 \\
\hline Cameroon & 1989 & 1989 & 1963 & Malawi & 1981 & 1988 & 1964 & Trin.\&Tob. & 1990 & & 1962 \\
\hline Chile & 1985 & 1985 & 1949 & Malaysia & & 1988 & 1957 & Tunisia & 1987 & & 1990 \\
\hline Colombia & 1985 & 1985 & 1981 & Mauritius & 1981 & & 1970 & Uruguay & 1987 & & 1953 \\
\hline Costa Rica & 1985 & 1985 & 1990 & Mexico & 1986 & 1985 & 1986 & Venezuela & 1989 & 1989 & 1990 \\
\hline El Salvador & 1991 & & 1991 & Niger & 1986 & & 1963 & Zaire & 1987 & & 1971 \\
\hline Ghana & 1987 & 1987 & 1957 & Pakistan & 1982 & 1988 & 1948 & Zambia & 1985 & & 1982 \\
\hline Guyana & 1981 & & 1966 & Peru & & 1989 & 1951 & & & & \\
\hline
\end{tabular}

Taken from Greenaway et.al. (2002) 
Figure 1: Standard Measures of Trade Policy, Split by GATT Membership

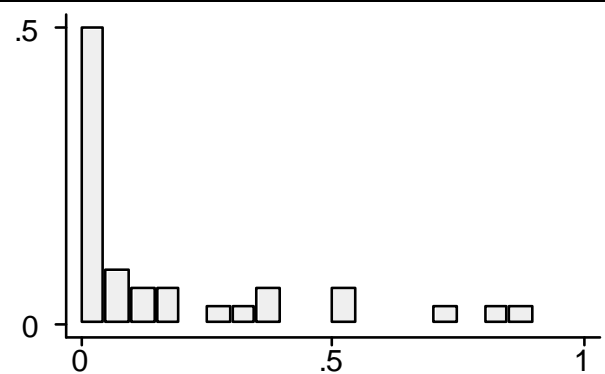

NTBs, (32) non-members

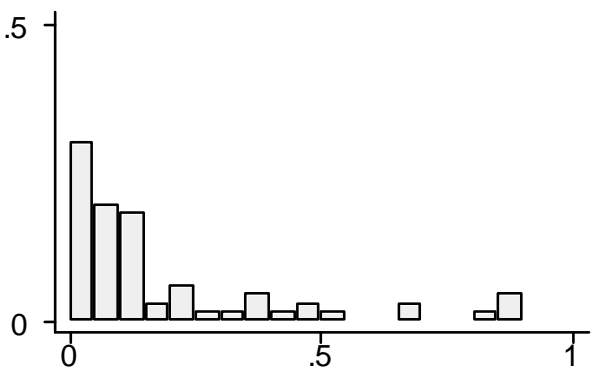

NTBs, (66) members

Barro-Lee data set

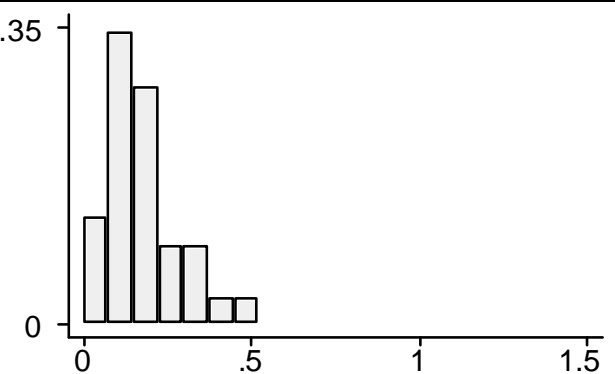

Tariffs, (32) non-members

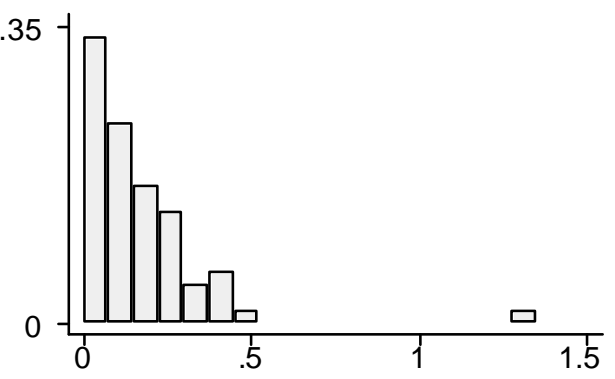

Tariffs, (68) members

\section{Trade Barriers in 1986, divided by GATT Membership}

Figure 2: Tariffs, Split by GATT/WTO Membership

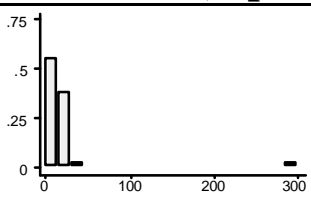

1977, (29) non-members

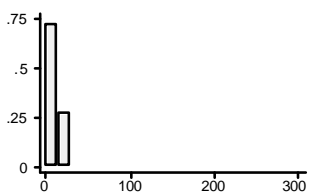

$1977,(63)$ members

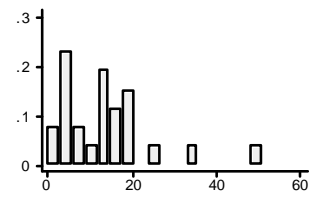

1989, (26) non-members

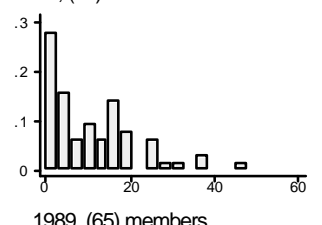

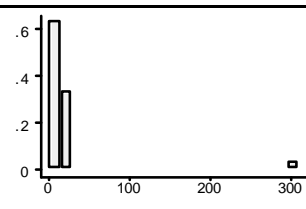

1980, (30) non-members

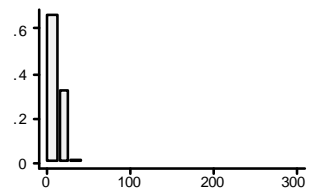

1980, (68) members

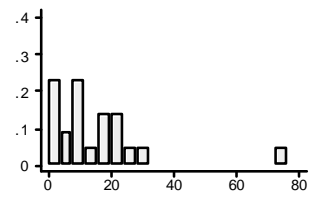

1992, (22) non-members

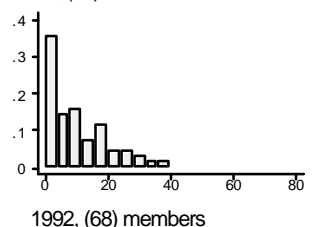

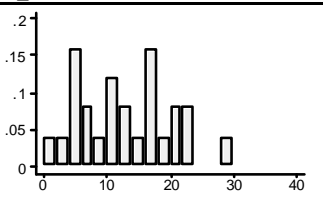

1983, (25) non-members

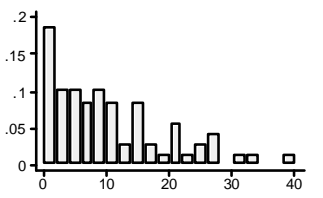

1983, (70) members

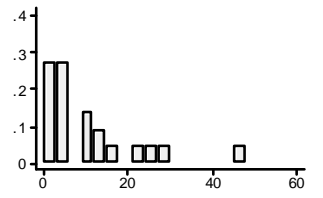

1995, (22) non-members

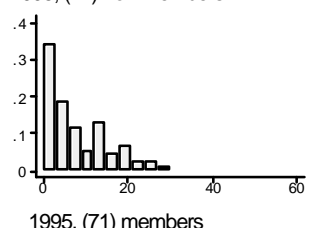

1995, (71) members

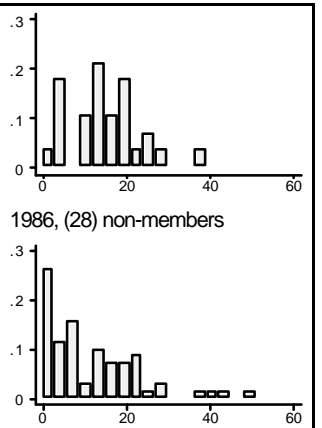

1986, (69) members

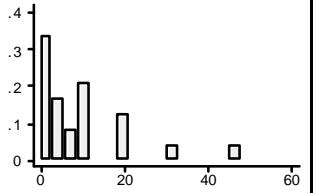

1998, (24) non-members

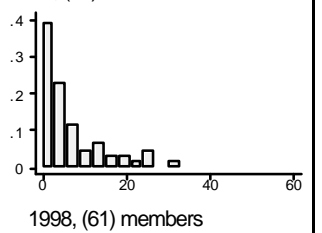

Data from WDI

Import Duties (\% Imports), by GATT/WTO Membership 
Figure 3: Effect of GATT/WTO Accession on Trade Policy

Five-year event study around (107) GATT/WTO accessions.

PWT6, 1950-1998; samples vary.

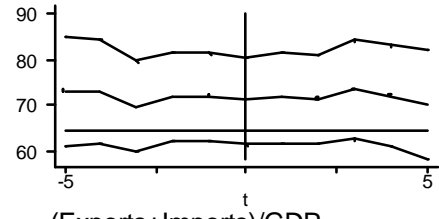

(Exports+Imports)/GDP

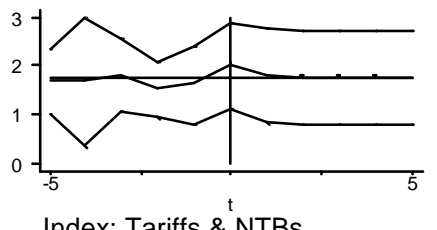

Index: Tariffs \& NTBs

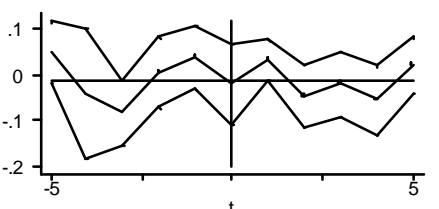

Movement to Int'I Prices

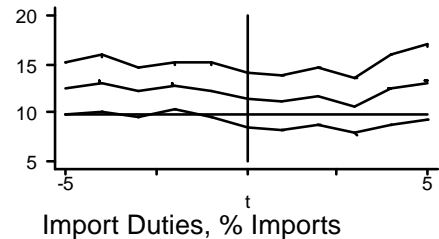

Import Duties, \% Imports
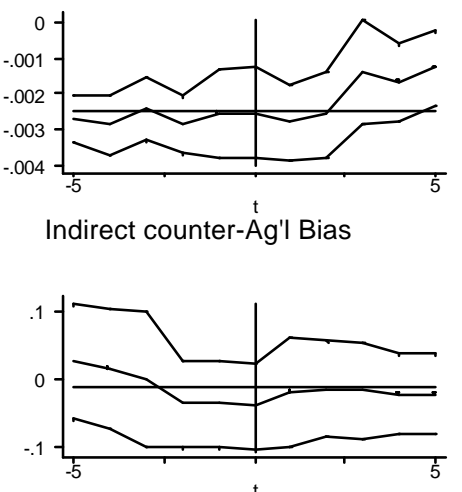

Price Distortion Measure
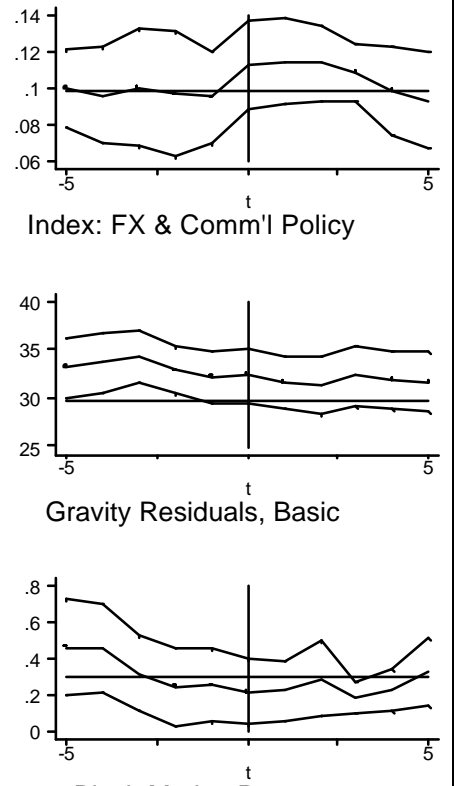

Black-Market Prem.

Mean, with +/- 2 standard deviations; GATT/WTO averages marked. Effect of GATT/WTO entry on Trade Policy 


\section{Appendix 1: Countries in Penn World Table 6 (pre-1999 GATT/WTO accession date)}

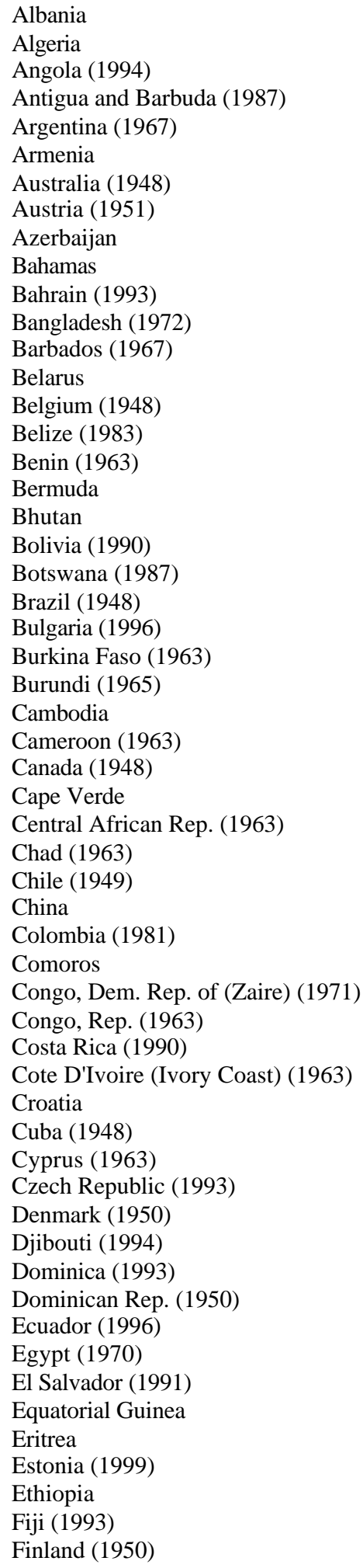

France (1948)

Gabon (1963)

Gambia (1965)

Georgia

Germany (1951)

Ghana (1957)

Greece (1950)

Grenada (1994)

Guatemala (1991)

Guinea (1994)

Guinea-Bissau (1994)

Guyana (1966)

Haiti (1950)

Honduras (1994)

Hong Kong (1986)

Hungary (1973)

Iceland (1968)

India (1948)

Indonesia (1950)

Iran

Ireland (1967)

Israel (1962)

Italy (1950)

Jamaica (1963)

Japan (1955)

Jordan

Kazakhstan

Kenya (1964)

Korea, South (R) (1967)

Kuwait (1963)

Kyrgyz Republic (1998)

Lao People's Dem. Rep.

Latvia (1999)

Lebanon

Lesotho (1988)

Lithuania

Luxembourg (1948)

Macao (1991)

Macedonia

Madagascar (1963)

Malawi (1964)

Malaysia (1957)

Mali (1993)

Malta (1964)

Mauritania (1963)

Mauritius (1970)

Mexico (1986)

Moldova

Mongolia (1997)

Morocco (1987)

Mozambique (1992)

Namibia (1992)

Nepal

Netherlands (1948)

New Zealand (1948)

Nicaragua (1950)
Niger (1963)

Nigeria (1960)

Norway (1948)

Oman

Pakistan (1948)

Panama (1997)

Papua N. Guinea (1994)

Paraguay (1994)

Peru (1951)

Philippines (1979)

Poland (1967)

Portugal (1962)

Puerto Rico (1948)

Qatar (1994)

Romania (1971)

Russia

Rwanda (1966)

Sao Tome \& Principe

Saudi Arabia

Senegal (1963)

Seychelles

Sierra Leone (1961)

Singapore (1973)

Slovak Republic (1993)

Slovenia (1994)

South Africa (1948)

Spain (1963)

Sri Lanka (1948)

St. Kitts \& Nevis (1994)

St. Lucia (1993)

St. Vincent \& Gren.(1993)

Sudan

Swaziland (1993)

Sweden (1950)

Switzerland (1966)

Syria

Taiwan

Tajikistan

Tanzania (1961)

Thailand (1982)

Togo (1964)

Trinidad \& Tobago (1962)

Tunisia (1990)

Turkey (1951)

Turkmenistan

Uganda (1962)

Ukraine

United Kingdom (1948)

United States (1948)

Uruguay (1953)

Uzbekistan

Venezuela (1990)

Vietnam

Yemen, Republic of

Zambia (1982)

Zimbabwe (1948) 
Appendix 2: Sample Values of Trade Policy Measures

\begin{tabular}{|c|c|c|c|c|c|c|c|c|c|}
\hline & $\begin{array}{l}(\mathrm{X}+\mathrm{M}) / \mathrm{Y} \\
1995(\%)\end{array}$ & $\begin{array}{l}\text { Tariffs } \\
1995(\%)\end{array}$ & IEF 1995 & $\begin{array}{l}\text { NTB } \\
\text { coverage } \\
1986\end{array}$ & $\begin{array}{l}1982 \text { FX } \\
\text { comm'l } \\
\text { policy } \\
\text { Index }\end{array}$ & $\begin{array}{l}\text { Tariffs } \\
\text { NTBs } \\
\text { Index, } \\
1982\end{array}$ & $\begin{array}{l}\text { Leamer } \\
\text { Index } \\
1982\end{array}$ & $\begin{array}{l}\text { Price } \\
\text { Distortion } \\
1982\end{array}$ & $\begin{array}{l}\text { Black } \\
\text { Market } \\
\text { Premium } \\
1982\end{array}$ \\
\hline Argentina & 19.8 & 8.5 & 2.75 & .06 & .08 & & -.14 & -.04 & .27 \\
\hline Australia & 39.4 & 4.5 & 2.05 & & & & -.01 & & \\
\hline Belgium & 136.2 & 0 & & .11 & & & .22 & & \\
\hline Brazil & 17.2 & & 3.3 & .05 & .08 & 1 & 0 & -.10 & .54 \\
\hline Canada & 72.6 & .3 & 2.05 & .02 & & & 0 & & \\
\hline China & 37.3 & 3.2 & 3.6 & .29 & & & & & .16 \\
\hline Egypt & 50.0 & 6.2 & 3.7 & .25 & & & -.33 & & .08 \\
\hline France & 43.6 & .0 & 2.3 & .05 & & & 0 & & \\
\hline Germany & 48.2 & 0 & 2.1 & .12 & & & .01 & & \\
\hline India & 25.0 & 4.8 & 3.8 & .89 & & & & -.04 & .12 \\
\hline Indonesia & 54.0 & 3.3 & 3.4 & .10 & .13 & 1 & .04 & -.05 & .01 \\
\hline Italy & 50 & .0 & 2.5 & .07 & & & .1 & & \\
\hline Japan & 17.3 & & 1.85 & .06 & & & 0 & & \\
\hline Korea & 61.9 & 4.7 & 2.15 & .1 & .17 & 3 & & .02 & .04 \\
\hline Mexico & 58.2 & 2.4 & 2.85 & .06 & & 1 & & -.16 & .07 \\
\hline Netherlands & 109.0 & 0 & & .13 & & & .14 & & \\
\hline Nigeria & 86.5 & & 3.25 & .02 & & & & & .61 \\
\hline Pakistan & 37.1 & 23.9 & 3.15 & .08 & .1 & 1 & -.03 & -.15 & .22 \\
\hline Singapore & 339.1 & .2 & 1.5 & .01 & & & .15 & .06 & .00 \\
\hline S. Africa & 45.1 & 5.7 & 3 & & & & & & \\
\hline Spain & 45.4 & .0 & 2.5 & .12 & .1 & & .04 & & .03 \\
\hline Sweden & 74.1 & 1.0 & 2.65 & .03 & & & -.03 & & \\
\hline Turkey & 44.2 & 3.2 & 2.8 & .87 & .09 & 2 & .02 & -.11 & .14 \\
\hline UK & 57.2 & 0 & 1.9 & .04 & & & .06 & & \\
\hline $\mathbf{U S}$ & 23.3 & 2.6 & 1.9 & .12 & & & 0 & & \\
\hline Zaire/Congo & 52.2 & 9.2 & & .38 & & & & & 1.08 \\
\hline
\end{tabular}




\section{Appendix 3: Trends in Trade Policy}

\begin{tabular}{|c|c|c|c|c|c|c|c|}
\hline $\begin{array}{l}\text { Dependent } \\
\text { Variable }\end{array}$ & Trend & Population & GDP $p / c$ & Remoteness & Obs. & $\overline{\mathbf{R}^{2}}$ & $\overline{\text { RMSE }}$ \\
\hline (Exports+Imports)/GDP & $\begin{array}{l}.27 \\
(.22)\end{array}$ & $\begin{array}{c}2.4 \\
(7.7)\end{array}$ & $\begin{array}{l}11.92 \\
(4.06)\end{array}$ & $\begin{array}{l}-167 \\
(65)\end{array}$ & 5499 & .87 & 16.2 \\
\hline $\begin{array}{l}\text { Import Duties as \% } \\
\text { imports }\end{array}$ & $\begin{array}{l}-.11 \\
(.12)\end{array}$ & $\begin{array}{c}.3 \\
(4.2)\end{array}$ & $\begin{array}{l}-1.65 \\
(1.57)\end{array}$ & $\begin{array}{l}11 . \\
(78)\end{array}$ & 2099 & .78 & 4.55 \\
\hline $\begin{array}{l}\text { Index from FX and } \\
\text { commercial policy }\end{array}$ & $\begin{array}{l}.004 \\
(.004)\end{array}$ & $\begin{array}{l}-.08 \\
(.10)\end{array}$ & $\begin{array}{l}-.02 \\
(.04)\end{array}$ & $\begin{array}{c}.00 \\
(1.2)\end{array}$ & 356 & .47 & .03 \\
\hline $\begin{array}{l}\text { Index from Tariffs and } \\
\text { NTBs }\end{array}$ & $\begin{array}{c}09 \\
(.10)\end{array}$ & $\begin{array}{l}-2.3 \\
(3.1)\end{array}$ & $\begin{array}{l}.39 \\
(.57)\end{array}$ & $\begin{array}{l}-156 \\
(56)\end{array}$ & 255 & .82 & .41 \\
\hline $\begin{array}{l}\text { Indirect counter- } \\
\text { agricultural bias }\end{array}$ & $\begin{array}{l}-.0001 \\
(.0001)\end{array}$ & $\begin{array}{l}.000 \\
(.004)\end{array}$ & $\begin{array}{c}.003 \\
(.001)\end{array}$ & $\begin{array}{l}-.050 \\
(.028)\end{array}$ & 396 & .60 & .001 \\
\hline $\begin{array}{l}\text { Gravity-Residuals, basic } \\
\text { model }\end{array}$ & $\begin{array}{l}.38 \\
(.09)\end{array}$ & $\begin{array}{l}-4.79 \\
(2.87)\end{array}$ & $\begin{array}{l}-4.35 \\
(1.50)\end{array}$ & $\begin{array}{c}19.5 \\
(56.0)\end{array}$ & 2502 & .86 & 3.88 \\
\hline $\begin{array}{l}\text { Movement to International } \\
\text { Prices }\end{array}$ & $\begin{array}{l}-.005 \\
(.003)\end{array}$ & $\begin{array}{l}.01 \\
(.12)\end{array}$ & $\begin{array}{l}.00 \\
(.04)\end{array}$ & $\begin{array}{l}-3.38 \\
(1.64)\end{array}$ & 539 & .24 & .127 \\
\hline $\begin{array}{l}\text { Modified Price Distortion } \\
\text { Index }\end{array}$ & $\begin{array}{l}.001 \\
(.007)\end{array}$ & $\begin{array}{l}-.17 \\
(.26)\end{array}$ & $\begin{array}{c}.04 \\
(.08)\end{array}$ & $\begin{array}{l}-3.31 \\
(2.13)\end{array}$ & 723 & .55 & .086 \\
\hline Black Market Premium & $\begin{array}{l}-.010 \\
(.013)\end{array}$ & $\begin{array}{l}.98 \\
(.57)\end{array}$ & $\begin{array}{l}-.45 \\
(.23)\end{array}$ & $\begin{array}{l}-2.7 \\
(7.1)\end{array}$ & 1407 & .36 & .405 \\
\hline
\end{tabular}

Population and real GDP per capita are included in natural logarithms from PWT6.

Constant and country-specific fixed effects included but not recorded.

Robust standard errors in parentheses. 


\section{Appendix 4: Changes in Trade Policy for GATT/WTO Members and Outsiders}

\begin{tabular}{|c|c|c|c|c|c|c|c|c|c|}
\hline \multicolumn{4}{|c|}{---- 1-year changes -.--- } & \multicolumn{3}{|c|}{---- 5-year changes -.--- } & \multicolumn{3}{|c|}{---- 10-year changes -..-- } \\
\hline $\begin{array}{l}\text { Trade Policy } \\
\text { Variable }\end{array}$ & Members & $\begin{array}{c}\text { non- } \\
\text { Members }\end{array}$ & $\begin{array}{c}\text { Equality } \\
\text { Test }\end{array}$ & Members & $\begin{array}{c}\text { non- } \\
\text { Members }\end{array}$ & $\begin{array}{c}\text { Equality } \\
\text { Test }\end{array}$ & Members & $\begin{array}{c}\text { non- } \\
\text { Members }\end{array}$ & $\begin{array}{c}\text { Equality } \\
\text { Test }\end{array}$ \\
\hline (Exports+Imports)/GDP & .52 & .66 & .65 & 3.55 & 4.81 & .41 & 3.57 & 3.66 & .98 \\
\hline $\begin{array}{l}\text { Import Duties as \% } \\
\text { imports }\end{array}$ & -.21 & -.26 & .92 & -.83 & .91 & .09 & .04 & 3.42 & .12 \\
\hline $\begin{array}{l}\text { Index from FX and } \\
\text { commercial policy }\end{array}$ & .001 & .000 & .74 & .019 & .007 & .40 & & & \\
\hline $\begin{array}{l}\text { Index from Tariffs and } \\
\text { NTBs }\end{array}$ & .10 & .13 & .78 & .44 & .50 & .91 & & & \\
\hline $\begin{array}{l}\text { Indirect counter- } \\
\text { agricultural bias }\end{array}$ & -.00 & -.00 & .34 & -.00 & -.00 & .18 & & & \\
\hline $\begin{array}{l}\text { Gravity-Residuals, } \\
\text { basic model }\end{array}$ & .16 & .11 & .63 & .84 & 1.01 & .89 & 1.73 & 1.34 & .70 \\
\hline $\begin{array}{l}\text { Gravity-Residuals, } \\
\text { augmented model }\end{array}$ & .20 & .19 & .92 & 1.00 & 1.29 & .61 & 2.09 & 2.13 & .97 \\
\hline $\begin{array}{l}\text { Movement to } \\
\text { International Prices }\end{array}$ & .001 & .006 & .78 & -.02 & .00 & .63 & .01 & -.05 & .36 \\
\hline $\begin{array}{l}\text { Modified Price } \\
\text { Distortion Index }\end{array}$ & -.003 & .001 & .19 & -.02 & .01 & .18 & .09 & .09 & .87 \\
\hline Black Market Premium & .01 & .01 & .85 & -.02 & .09 & .11 & .04 & .07 & .79 \\
\hline
\end{tabular}

Simple differences tabulated for GATT/WTO members and non-members.

P-values for t-tests of equality between GATT/WTO members and non-members. Small values imply rejection of null hypothesis (equal changes in trade policy for GATT/WTO members and non-members).

5- and 10-year changes are for non-overlapping data. 


\section{References}

Bagwell, Kyle and Robert Staiger (1999) “An Economic Theory of GATT” American Economic Review 89-1, 215-248.

Bagwell, Kyle and Robert Staiger (2000) “GATT-Think” unpublished.

Barro, Robert J. and Jong-Wha Lee (2002) "IMF Programs: Who is Chosen and What are the Effects?” NBER Working Paper No. 8951.

Curzon, Gerard (1965) Multilateral Commercial Diplomacy (London: Michael Joseph).

Dam, Kenneth W. (1970) The GATT - Law and International Economic Organization (Chicago, University Press).

Dollar, David (1992) “Outward-Oriented Developing Countries Really Do Grow More Rapidly" Economic Development and Cultural Change, 523-544.

Easterly, William (2001) "The Effect of International Monetary Fund and World Bank Programs on Poverty” World Bank working paper No. 2517.

Edwards, Sebastian (1997) "Openness, Productivity and Growth: What do we Really Know?" NBER Working Paper No. 5978.

Goldberg, Pinelopi Koujianou and Giovanni Maggi (1999) "Protection for Sale: An Empirical Investigation” American Economic Review 89-5, 1135-1155.

Greenaway, David, Wyn Morgan and Peter Wright (2002) "Trade Liberalisation and Growth in Developing Countries” Journal of Development Economics 67, 229-244.

Grossman, Gene and Elhanan Helpman (1994) "Protection for Sale" American Economic Review 84-4, 833-850.

Grossman, Gene and Elhanan Helpman (1995) “Trade Wars and Trade Talks" Journal of Political Economy 103-4, 675-708.

Haque, N. and Mohsin S. Kahn (1998) "Do IMF-Supported Programs Work? A Survey of the Cross-Country Empirical Evidence” IMF Working Paper WP/98/169.

Harrison, Ann (1996) "Openness and Growth: A Time-Series, Cross-Country Analysis for Developing Countries” Journal of Development Economics 48, 419-447.

Heitger, Bernard (1987) "Import Protection and Export Performance - Their Impact on Economic Growth” Weltwirtschaftliches Archiv 123-2, 249-261. 
Hiscox, Michael J. and Scott L. Kastner (2002) “A General Measure of Trade Policy Orientations: Gravity-Model-Based Estimates for 83 Nations, 1960 to 1992” UCSD working paper.

Irwin, Douglas A. (1995) "The GATT in Historical Perspective" American Economic Review 852, 323-328.

Jackson, John H. (1969) World Trade and the Law of GATT (New York: Bobb-Merrill).

Krueger, Anne O. (1978) Liberalization Attempts and Consequences (Ballinger: New York).

Krueger, Anne O. (1998) "Introduction" in The WTO as an International Organization (Chicago: University Press).

McMillan, Margaret, Dani Rodrik and Karen Horn Welch (2002) "When Economic Reform Goes Wrong: Cashews in Mozambique” NBER Working Paper No. 9117.

Papageorgiou, Demetrios, Armeane M. Choksi and Michael Michaely (1990) Liberalizing Foreign Trade in Developing Countries: The Lessons of Experience (World Bank: Washington).

Pritchett, Lant (1996) "Measuring Outward Orientation in LDCs: Can it be done?" Journal of Development Economics 49-2, 307-335.

Rodriguez, Francisco and Dani Rodrik (2000) “Trade Policy and Economic Growth: A Skeptic's Guide to the Cross-National Evidence" NBER Macroeconomics Annual 261-338.

Rodrik, Dani (1995) "Political Economy of Trade Policy" in Handbook of International Economics vol. III (Grossman and Rogoff, editors; Elsevier Science, Amsterdam).

Rose, Andrew K. (2002) “Do We Really Know that the WTO increases Trade?” working paper.

Sachs, Jeffrey D. and Andrew Warner (1995) "Economic Reform and the Process of Global Integration" Brookings Papers on Economic Activity 1, 1- .

Staiger, Robert (1995) "International Rules and Institutions for Trade Policy" in Handbook of International Economics vol. III (Grossman and Rogoff, editors; Elsevier Science, Amsterdam).

Trefler, Daniel (1993) “Trade Liberalization and the Theory of Endogenous Protection” Journal of Political Economy 101-1, 138-160.

World Bank, Annual Review of Development Effectiveness, various issues. 


\section{Endnotes}

${ }^{1}$ On the IMF: Haque and Kahn (1998) provide a view from inside the Fund, while Barro and Lee (2002) provide an external perspective. Two analogies on the Bank: are the World Bank's Annual Review of Development Effectiveness and McMillan, Rodrik and Welch (2002). Also see, among many others, Easterly (2001).

${ }^{2}$ On the left, see among many others, the website of the "International Forum on Globalization" www.ifg.org. On the right, try the Economist (e.g., "Clueless in Seattle" Dec 2, 1999 or even more strikingly "Who Needs the WTO" from the same issue which begins "For five decades the world's multilateral trade-liberalising machinery - known first as the General Agreement on Tariffs and Trade (GATT) and more recently as the World Trade Organisation (WTO) - has, in all likelihood, done more to attack global poverty and advance living standards right across the planet than has any other man-made device.").

${ }^{3}$ Suggestions are welcome!

${ }^{4}$ See http://www.wto.org/english/thewto_e/whatis_e/inbrief_e/inbr00_e.htm, http://www.wto.org/english/thewto_e/whatis_e/tif_e/fact0_e.htm, and http://www.wto.org/english/thewto_e/whatis_e/tif_e/agrm0_e.htm

${ }^{5}$ The PWT6 is freely available at http://webhost.bridgew.edu/baten.

${ }^{6}$ As Pritchett notes, import data may be preferred to total trade since better information is available on barriers to imports.

${ }^{7}$ I drop one of Harrison's measures (trade as a fraction of GDP) since it is highly correlated with more recent data that measure the same thing. The simple correlation of her measure of openness with more recent data on (Exports+Imports)/GDP is .95.

${ }^{8}$ That is, remoteness $\mathrm{i}_{\mathrm{i}, \mathrm{t}}=\mathrm{J} / \mathrm{\Sigma}_{\mathrm{j}} \mathrm{Y}_{\mathrm{j}, \mathrm{t}} / \mathrm{D}_{\mathrm{ij}}$ where $\mathrm{Y}_{\mathrm{j}, \mathrm{t}}$ is the $\log$ of real GDP for $\mathrm{j}$ at $\mathrm{t}$, and $\mathrm{D}_{\mathrm{ij}}$ is the log distance between $\mathrm{i}$ and $\mathrm{j}$.

9 The data set is described and available at: http://www.cidcm.umd.edu/inscr/polity/ The polity variable is significantly positive correlated with membership in the GATT/WTO. For instance, the $\mathrm{t}$-statistic for a simple regression of GATT/WTO membership on polity exceeds 30, and strong results persist when country- or yeareffects are added. It is less clear that a country's polity score is truly exogenous, though it is in practice uncorrelated with the vast majority of measures of trade policy.

I have also used geographic instrumental variables (such as a country's land mass, latitude, and landlocked/island status) with results similar to those tabulated below.

${ }^{10}$ The $\mathrm{t}$-statistics for the null hypothesis of equal NTB coverage and tariff rates for GATT and non-GATT members are .2 and .1 respectively, consistent with the null at all reasonable levels. Yet these are precisely the measures advocated by Rodriguez and Rodrik.

${ }_{11}$ The outlier is Sudan with tariffs of around $300 \%$ of imports.

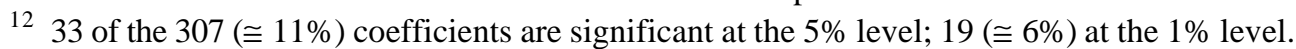

13 Appendix 4 tabulates changes in the panel trade policy measures at three horizons: 1-, 5-, and 10-years. At each horizon, a simple $t$-test is tabulated for the null hypothesis that the change in trade policy is equal for GATT/WTO members and non-members. None of these $t$-statistics is significantly different from zero at conventional significance levels, consistent with the hypothesis that not only levels but also changes in trade policy are similar for GATT members and non-members.

${ }^{14}$ One imperfect way to gauge the noise in the data set is to substitute membership in a regional free trade association for membership in the GATT/WTO. Clearly membership in a regional trade agreement is bilateral, whereas membership in the GATT/WTO is a multilateral phenomenon, so noise should be even higher. Yet members of FTAs tend to have more trade relative to GDP, lower tariffs, and more economic freedom. These phenomena are also present much more frequently; for instance, of the 12 statistical perturbation (=OLS/Multivariate/IV x 4 sets of fixed effects), 9 are significantly negative for tariffs, 10 are significantly negative for IEF, and 6 are significantly positive for openness.

${ }^{15}$ See also the negative results on changes in trade policy tabulated in Appendix 4. 